Aritoshi lida - Susumu Saito - Akihiro Sekine

Chihiro Mishima • Yuri Kitamura • Kimie Kondo

Satoko Harigae $\cdot$ Saori Osawa $\cdot$ Yusuke Nakamura

\title{
Catalog of 605 single-nucleotide polymorphisms (SNPs) among 13 genes encoding human ATP-binding cassette transporters: ABCA4, ABCA7, ABCA8, ABCD1, ABCD3, ABCD4, ABCE1, ABCF1, ABCG1, ABCG2, ABCG4, $A B C G 5$, and $A B C G 8$
}

Received: February 26, 2002 / Accepted: March 5, 2002

\begin{abstract}
Single-nucleotide polymorphisms (SNPs) at some gene loci are useful as markers of individual risk for adverse drug reactions or susceptibility to complex diseases. We have been focusing on identifying SNPs in and around genes encoding drug-metabolizing enzymes and transporters, and have constructed several high-density SNP maps of such regions. Here we report SNPs at additional loci, specifically 13 genes belonging to the superfamily of ATPbinding cassette transporters ( $A B C A 4, A B C A 7, A B C A 8$, $A B C D 1, A B C D 3, A B C D 4, A B C E 1, A B C F 1, A B C G 1$, $A B C G 2, A B C G 4, A B C G 5$, and $A B C G 8)$. Sequencing a total of $416 \mathrm{~kb}$ of genomic DNA from 48 Japanese volunteers identified 605 SNPs among these 13 loci: 14 in 5' flanking regions, 5 in $5^{\prime}$ untranslated regions, 37 within coding elements, 529 in introns, 8 in $3^{\prime}$ untranslated regions, and 12 in $3^{\prime}$ flanking regions. By comparing our data with SNPs deposited in the dbSNP database of the National Center for Biotechnology Information (US) and with published reports, we determined that 491 (81\%) of the SNPs reported here were novel. We also detected 107 genetic variations of other types among the loci examined (insertion-deletions or mono- di-, or trinucleotide polymorphisms). The high-density SNP maps we constructed on the basis of these data should provide useful information for investigating associations between genetic variations and common diseases or responsiveness to drug therapy.
\end{abstract}

Key words Single-nucleotide polymorphisms (SNPs) . Insertion-deletion polymorphisms - High-density SNP

A. Iida $\cdot$ S. Saito $\cdot$ A. Sekine $\cdot$ C. Mishima $\cdot$ Y. Kitamura $\cdot$ K. Kondo $\cdot$ S. Harigae $\cdot$ S. Osawa $\cdot$ Y. Nakamura

Laboratory for Genotyping, RIKEN SNP Research Center, Tokyo, Japan

Y. Nakamura $(\bowtie)$

Laboratory of Molecular Medicine, Human Genome Center,

Institute of Medical Science, The University of Tokyo, 4-6-1

Shirokanedai, Minato-ku, Tokyo 108-8639, Japan

Tel. +81-3-5449-5372; Fax +81-3-5449-5433

e-mail: yusuke@ims.u-tokyo.ac.jp maps - ATP-binding cassette transporter genes - Japanese population

\section{Introduction}

Single-nucleotide polymorphisms (SNPs) at some gene loci can be useful markers of individual risk for adverse drug reactions or susceptibility to complex diseases, because an SNP itself may influence the quality and/or quantity of a gene product (see a review by McCarthy and Hilfiker 2000). With this in mind, investigators in many laboratories have undertaken projects to establish large collections of SNPs across the human genome (Sachidanandam et al. 2001). In the near future, the genomic approach, combining the large collection of SNPs and high-throughput genotyping procedures based on that information, is likely to revolutionize drug discovery and development as well as the practice of medicine (Gray et al. 2000; Meyer 2000; Roses 2000). Recently, we have focused on genetic loci corresponding to drug-metabolizing enzymes and transporters and have already described more than 1500 variations in those regions (Iida et al. 2001a-e, 2002a,b; Saito et al. 2001a,b, 2002a,b; Sekine et al. 2001).

The ATP-binding cassette $(A B C)$ transporter superfamily is one of the largest gene families. These genes encode a functionally diverse group of membrane proteins involved in energy-dependent transport of a wide variety of substrates across membranes (see reviews by Allikmets et al. 1996; Broccardo et al. 1999; Klein et al. 1999; Dean et al. 2001). Eukaryotic ABC transporters are organized either as full transporters containing two transmembrane domains and two nucleotide-binding folds, or as half-transporters. Molecules of the latter type must form either homodimers or heterodimers to constitute functional transporters. The entire group is divided into seven distinct subfamilies on the basis of predicted protein structures and phylogenetic analysis. So far, a total of 48 human transporter genes belonging to one or other of the seven $A B C$ subfamilies has been reported (http://nutrigene.4t.com/humanabc.htm). 
Some genetic variations present in genes that encode drug transporters and drug-metabolizing enzymes are likely to be associated with susceptibility to common diseases as well as with differences in therapeutic efficacy and/or side effects of drugs among individuals. Therefore, information concerning genetic variations in human transporter genes should be an important resource for understanding not only the etiology and risk of some diseases, but also the pharmacokinetics or pharmacodyamics of drugs. Regarding SNP analysis in the $A B C$ transporter genes, we previously reported the construction of high-density SNP maps in the genomic segments corresponding to nine $A B C$ transporter subfamily B genes, and eight $A B C$ transporter subfamily C genes (Saito et al. 2002a,b). In this article, we provide highresolution maps of $13 A B C$ transporter (subfamilies $A, D$, $E, F$, and $G$ ) gene loci containing a total of 605 SNPs and 107 insertion-deletion polymorphisms that we detected in DNA from 48 Japanese volunteers.

\section{Subjects and methods}

Blood samples were obtained with written informed consent from 48 healthy Japanese volunteers for this study, which was approved by the ethical committee of the RIKEN SNP Research Center. The detailed methods used to screen for SNPs are available from our website (http://snp.ims.u-tokyo.ac.jp/). In brief, we sequenced 96 chromosomes to screen SNPs using polymerase chain reaction (PCR) primers to amplify an entire gene, including about $2 \mathrm{~kb}$ upstream of the first exon and downstream from the last exon, but excluding repetitive sequences. Each PCR was carried out using $20 \mathrm{ng}$ of pooled DNA for three individuals. All SNPs detected by the PolyPhred computer program (Nickerson et al. 1997) were confirmed by sequencing both strands of each PCR product.

Genbank accession numbers for the $13 A B C$ loci examined are as follows:

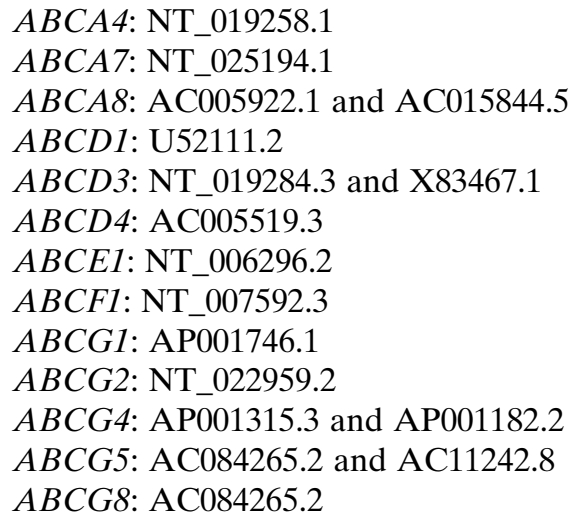

\section{Results and discussion}

Sequencing of about $416 \mathrm{~kb}$ of genomic DNA corresponding to 13 loci containing $A B C$ transporter genes identified a total of 712 variations among 96 Japanese chromosomes, including 605 SNPs and 107 variations of other types. The exon-intron organization of each gene and locations of SNPs identified within each locus are illustrated schematically in Fig. 1; detailed information is given in Table 1. The classification of SNPs on the basis of their locations is also summarized in Table 2. Among the 605 SNPs, 14 were located in $5^{\prime}$ flanking regions, 5 in $5^{\prime}$ untranslated regions, 37 in coding regions, 529 in introns, 8 in $3^{\prime}$ untranslated regions, and 12 in $3^{\prime}$ flanking regions. The 17 nonsynonymous SNPs were among 37 coding SNPs we found. Although the frequency of nonsynonymous SNPs was a very small part of the total SNP counts $(2.8 \%)$, the SNPs would likely influence protein function. By comparing our data with reports from elsewhere (Maugeri et al. 1999; Dvorakova et al. 2001; Hubacek et al. 2001; Lee et al. 2001; Lu et al. 2001) and the SNPs deposited in the dbSNP database at the National Center for Biotechnology Information, we were able to consider 491 of the 605 SNPs $(81 \%)$ to be novel (Tables 1 and 2). In addition, the overall frequencies of nucleotide substitutions were counted as $40 \%$ for $\mathrm{A} / \mathrm{G}$, $33.9 \%$ for $\mathrm{C} / \mathrm{T}, 8.6 \%$ for $\mathrm{A} / \mathrm{C}, 8.1 \%$ for $\mathrm{C} / \mathrm{G}, 6.1 \%$ for $\mathrm{G} / \mathrm{T}$, and $3.3 \%$ for $\mathrm{T} / \mathrm{A}$ (Table 3 ).

\section{$A B C A$ genes}

The ABC subfamily A comprises a group of full-size transporters characterized by the presence of a highly hydrophobic segment between two transmembrane domains. On the basis of database for "expressed sequence tags" (dbEST) information, current estimates suggest that at least 11 $A B C A$ genes are present in the human genome (Broccardo et al. 1999).

$A B C A 4$ locus. The $A B C A 4$ (sometimes referred as $A B C R$ ) gene is expressed highly and exclusively in the retina, and encodes the outer-segment rim protein of rods (Allikmets et al. 1997). Mutations of $A B C A 4$ have been implicated in a variety of retinal degenerative diseases associated with loss of vision (Klein et al. 1999; Dean et al. 2001). By screening approximately $84.5 \mathrm{~kb}$ at the $A B C A 4$ locus, we identified a total of 168 SNPs; 3 were in the $5^{\prime}$ flanking region, 4 were in coding regions, and 161 were in introns. No SNPs were found in $5^{\prime}$ untranslated, $3^{\prime}$ untranslated, or $3^{\prime}$ flanking regions. The average distribution of SNPs at this locus was 1 in every 503 nucleotides. The frequency of each type of substitution was $39.9 \%$ for $\mathrm{A} / \mathrm{G}, 32.1 \%$ for $\mathrm{C} / \mathrm{T}, 11.3 \%$ for $\mathrm{A} / \mathrm{C}, 8.3 \%$ for $\mathrm{C} / \mathrm{G}, 6.0 \%$ for $\mathrm{G} / \mathrm{T}$, and $2.4 \%$ for $\mathrm{T} / \mathrm{A}$. We also found 34 variations of other types at the $A B C A 4$ locus.

$A B C A 7$ locus. The $A B C A 7$ gene encodes a 2146 -aminoacid peptide (Kaminski et al. 2000). Northern blotting has revealed predominant expression in myelolymphatic tissues such as bone marrow, thymus, spleen, and peripheral blood. $A B C A 7$ is a sterol-sensitive gene that is inversely regulated by cholesterol import and export in macrophages; this regulatory response to cholesterol influx and efflux is similar to that of $A B C A 1$ and $A B C G 1$. Hence, Kaminski et 


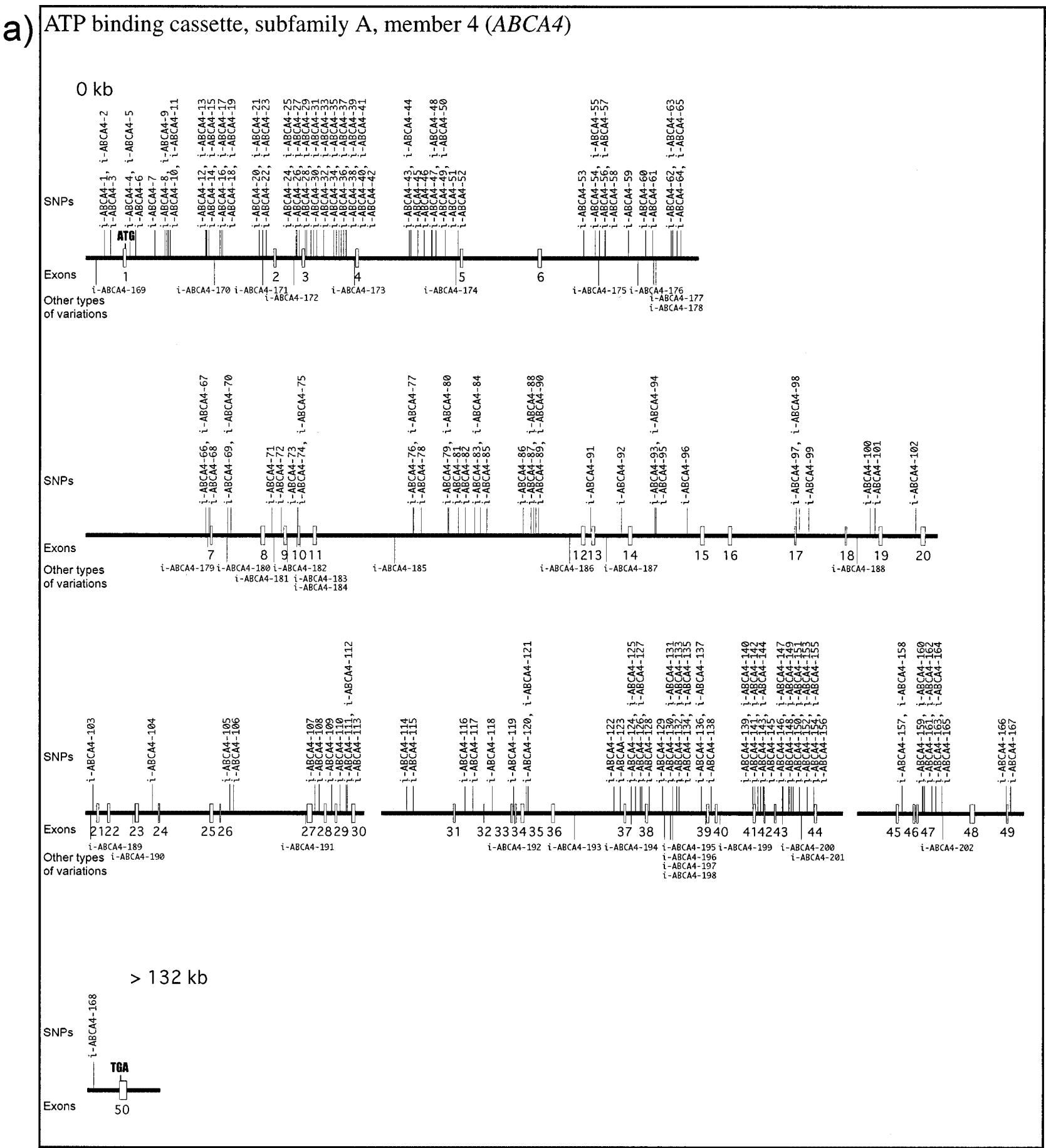

Fig. 1a-l. Genomic organizations and locations of single-nucleotide polymorphisms (SNPs) in 13 regions containing ATP-binding cassette transporter genes. Exons and introns are represented by rectangles and

al. (2000) suggested that $A B C A 7$ might function as a cellular lipid exporter. By screening an approximately 21.2-kb region at the $A B C A 7$ locus, we identified a total of 67 SNPs (4 in the $5^{\prime}$ flanking region, 1 in the $5^{\prime}$ untranslated region, 19 in coding regions, 37 in introns, 1 in the $3^{\prime}$ untranslated region, and 5 in the $3^{\prime}$ flanking region). The distribution of SNPs at this locus was 1 per $316 \mathrm{bp}$ on average. The frequency of each type of substitution was horizontal lines, respectively. SNPs are indicated above the genes (designations correspond to those in the left-most column in Table 1). Other types of variations are indicated below the genes

$44.8 \%$ for $\mathrm{A} / \mathrm{G}, 29.9 \%$ for $\mathrm{C} / \mathrm{T}, 7.5 \%$ for $\mathrm{A} / \mathrm{C}, 13.4 \%$ for $\mathrm{C} / \mathrm{G}, 3.0 \%$ for $\mathrm{G} / \mathrm{T}$, and $1.5 \%$ for $\mathrm{T} / \mathrm{A}$. We also found four other variations at the $A B C A 7$ locus.

$A B C A 8$ locus. $A B C A 8$, located in the $A B C A$-transporter cluster of genes on chromosome $17 \mathrm{q} 24$, was isolated from human brain libraries during cDNA-sequencing projects (Nagase et al. 1998; Dean et al. 2001). ABCA8 may function 
b) ATP binding cassette, subfamily A, member 7 ( $A B C A 7$ )
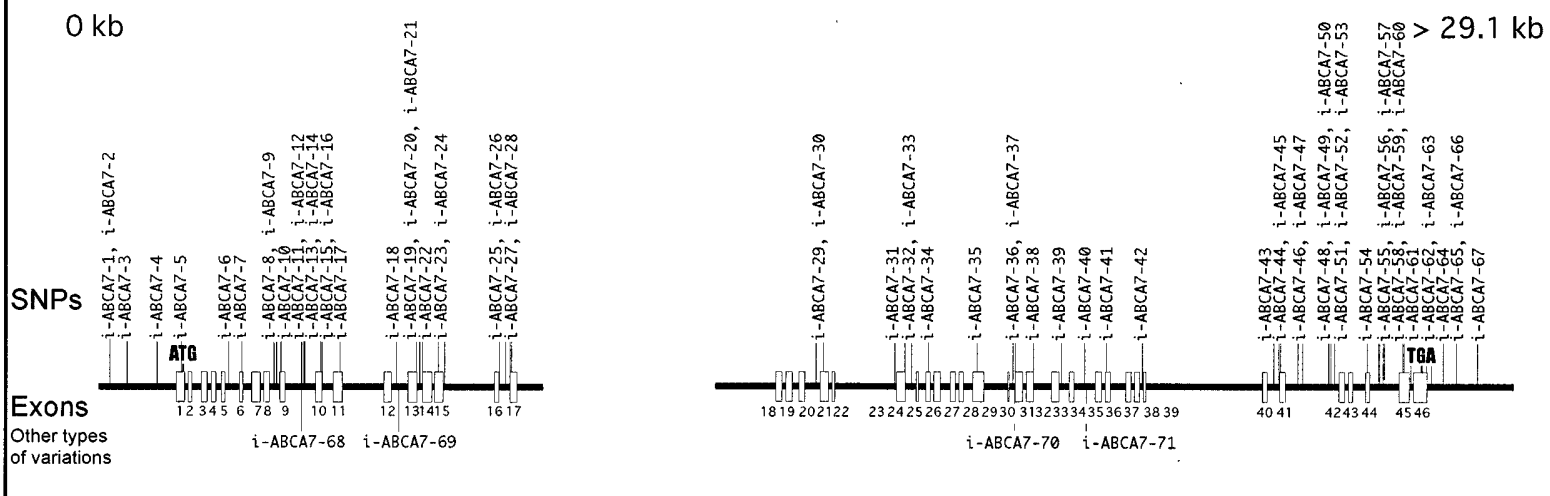

C) ATP binding cassette, subfamily A, member 8 (ABCA8)

$0 \mathrm{~kb}$

$35.4 \mathrm{~kb}$

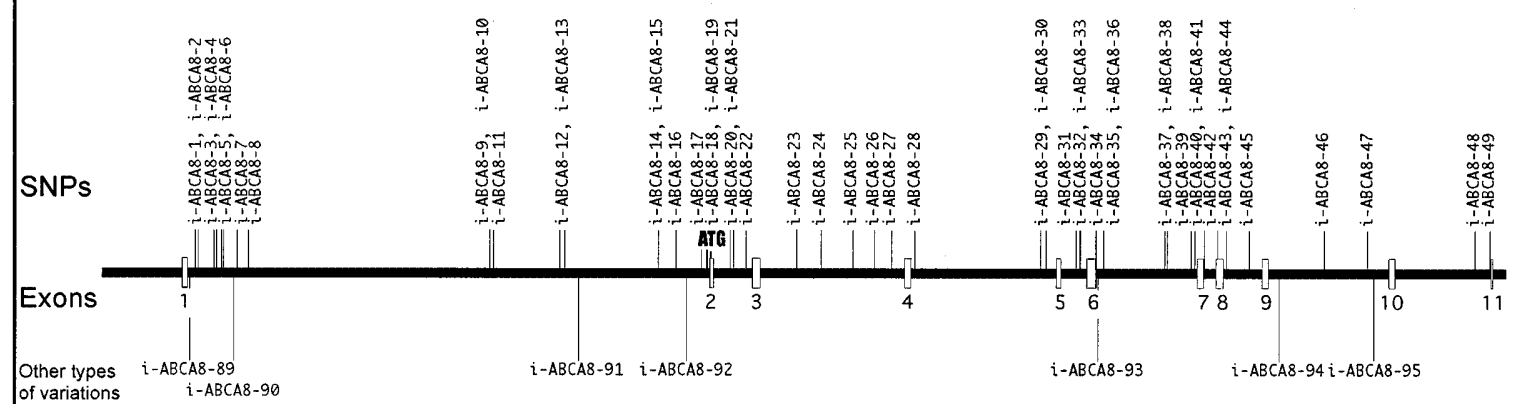

$35.4 \mathrm{~kb}$

$70.1 \mathrm{~kb}$

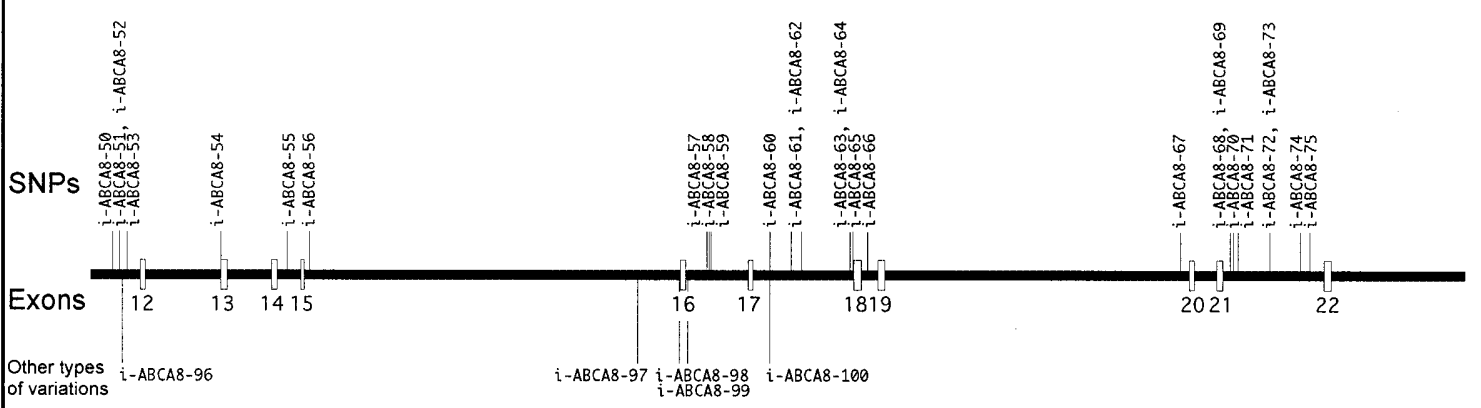

$70.1 \mathrm{~kb}$

$92.5 \mathrm{~kb}$

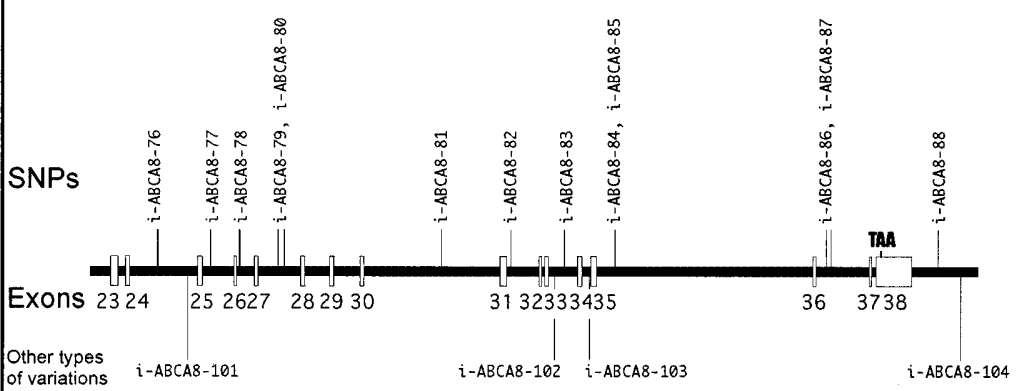

Fig. 1a-l. Continued 
d) ATP binding cassette, subfamily D, member $1(A B C D 1)$

$0 \mathrm{~kb}$

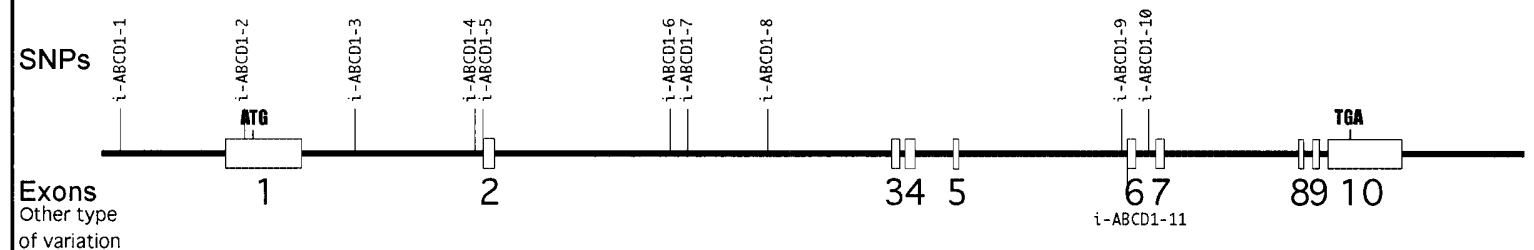

of variation

e) ATP binding cassette, subfamily $\mathrm{D}$, member $3(A B C D 3)$

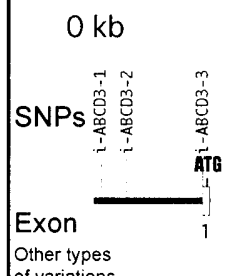

of variation

(2)

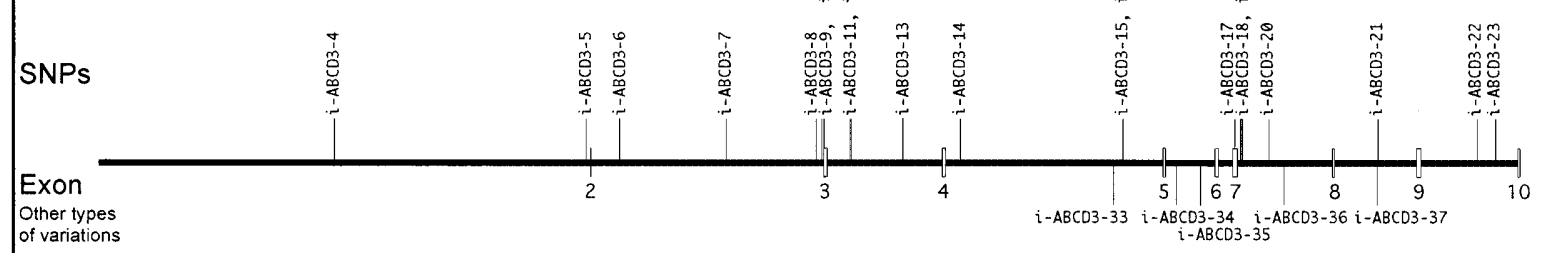

Other types

i-ABCD3-33 $\underset{i-A B C D 3-34 i-A B C D 3-35}{i-A B C D 3-36 i-A B C D 3-37}$

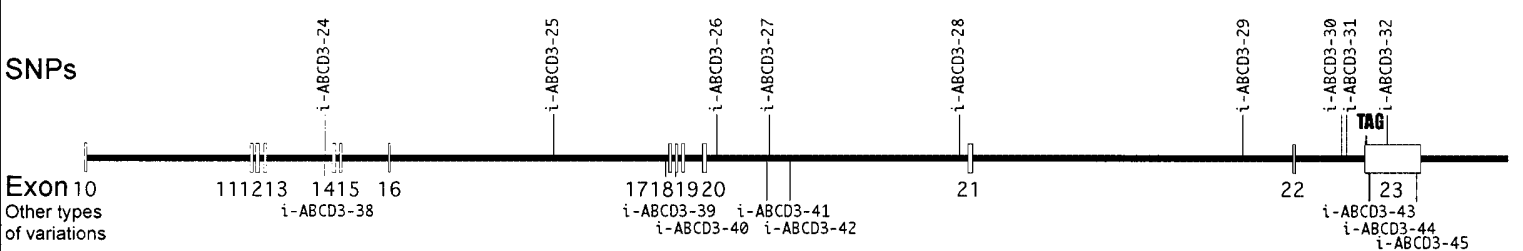

f) ATP binding cassette, subfamily D, member 4 (ABCD4) $0 \mathrm{~kb}$
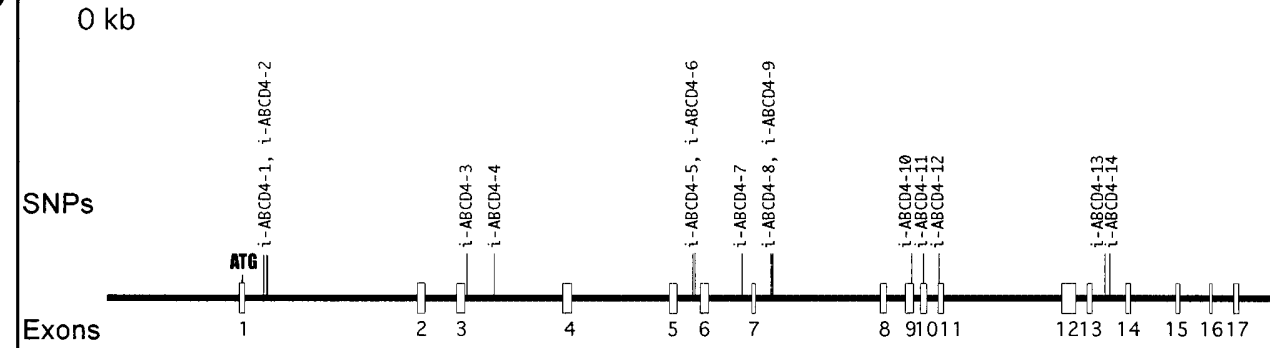

$21.5 \mathrm{~kb}$

Fig. 1a-l. Continued 

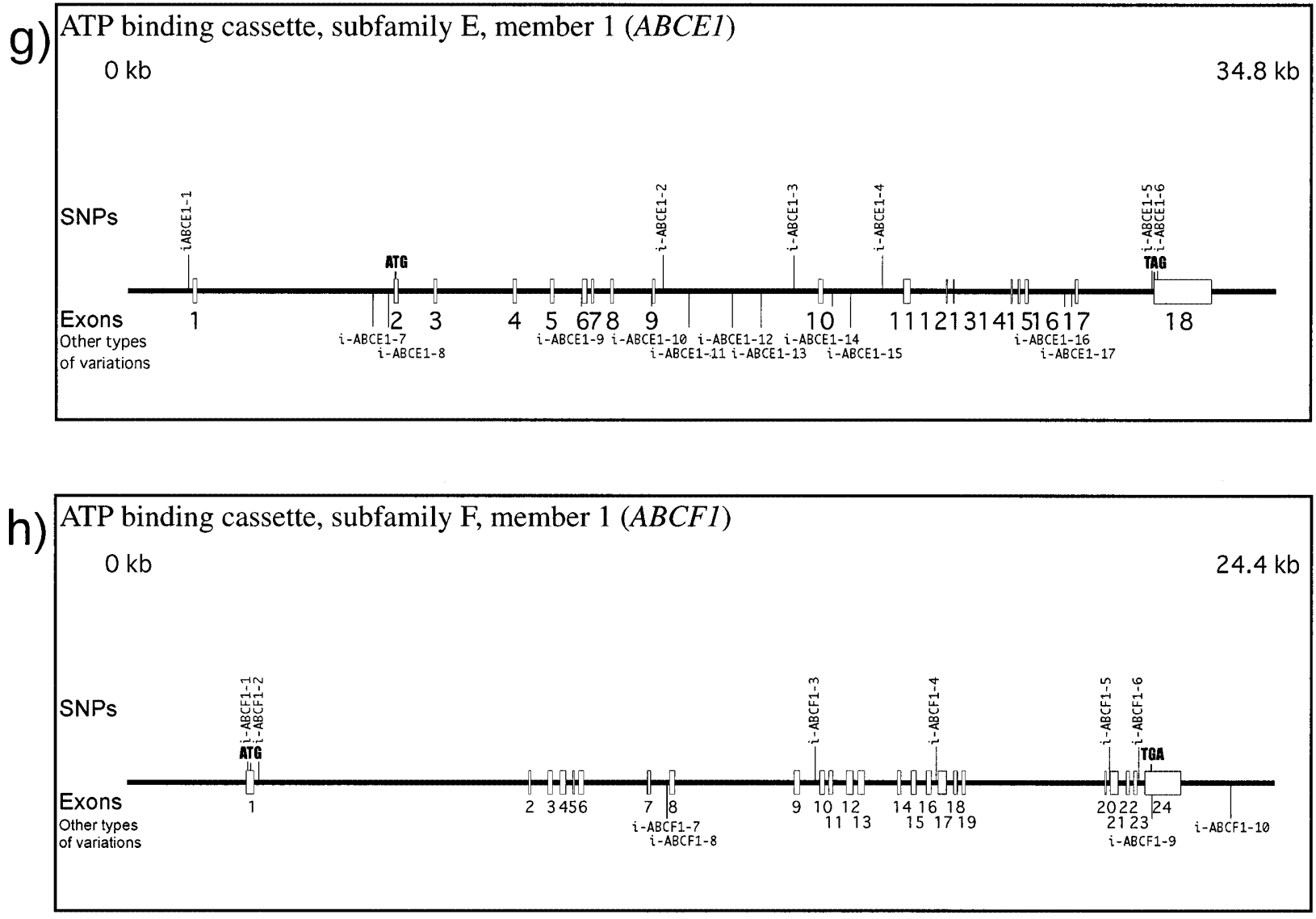

Fig. 1a-l. Continued

as a lipid transporter, but that has not been proven. Screening a region of approximately $57.7 \mathrm{~kb}$ encompassing the $A B C A 8$ gene detected a total of 88 SNPs: 3 in coding regions, 84 in introns, and 1 in the $3^{\prime}$ flanking region. The distribution of SNPs at this locus was 1 per $656 \mathrm{bp}$ on average. The frequency of each type of substitution was $40.9 \%$ for $\mathrm{A} / \mathrm{G}, 33.0 \%$ for $\mathrm{C} / \mathrm{T}, 5.7 \%$ for $\mathrm{A} / \mathrm{C}, 10.2 \%$ for $\mathrm{C} / \mathrm{G}, 5.7 \%$ for $\mathrm{G} / \mathrm{T}$, and $4.5 \%$ for $\mathrm{T} / \mathrm{A}$. We also found 16 variations of other types at this locus.

\section{$A B C D$ genes}

The ABCD subfamily at present consists of four genes, $A B C D 1, A B C D 2, A B C D 3$, and $A B C D 4$; all of them encode half-transporters located in the peroxisome, where their homo- and/or heterodimers regulate transport of very long chain fatty acids (Dean et al. 2001).

$A B C D 1$ locus. Positional cloning has characterized $A B C D 1$, encoding a 745-amino-acid protein, as the "causative gene" for X-linked adrenoleukodystrophy (Mosser et al. 1993). ABCD1 may play a role in the import or anchoring of the peroxisome enzyme VLCF-CoA synthase (Dodd et al. 1997). Screening of an approximately 15-kb region containing the $A B C D 1$ gene identified a total of 10 SNPs: 1 in the $5^{\prime}$ flanking region, 1 in the $5^{\prime}$ untranslated region, and 8 in introns. The distribution of SNPs at this locus was 1 per $1499 \mathrm{bp}$ on average. The frequency of each type of substitution was $30 \%$ for $A / G$ and $70 \%$ for $\mathrm{C} / \mathrm{T}$. We also found a one-base deletion polymorphism in intron 5 .

$A B C D 3$ locus. $A B C D 3$ gene encodes a $70-\mathrm{kDa}$ peroxisomal membrane protein (PXMP70) in the liver, and its mutations are responsible for Zellweger syndrome in some patients with this lethal inborn defect of peroxisome assembly (Gartner et al. 1992). Screening of approximately $37.1 \mathrm{~kb}$ encompassing the $A B C D 3$ gene identified a total of 32 SNPs: 2 in the $5^{\prime}$ flanking region, 1 in the $5^{\prime}$ untranslated region, 2 in coding regions, 26 in introns, and 1 in the $3^{\prime}$ untranslated region. The distribution of SNPs at this locus was 1 per $1158 \mathrm{bp}$ on average. The frequency of each type of substitution was $53.1 \%$ for $\mathrm{A} / \mathrm{G}, 28.1 \%$ for $\mathrm{C} / \mathrm{T}, 9.4 \%$ for $\mathrm{A} / \mathrm{C}, 3.1 \%$ for $\mathrm{G} / \mathrm{T}$, and $6.3 \%$ for $\mathrm{T} / \mathrm{A}$. We also found 13 variations of other types at this locus.

$A B C D 4$ locus. ABCD4, a 606-amino-acid protein located at the peroxisomal membrane, is a half-ABC transporter (Holzinger et al. 1997), but its amino acid sequence is not highly homologous to ABCD1 (24.5\%), ABCD2 (24.9\%), or ABCD3 (27.4\%) (Shani et al. 1997). Screening approximately $13.4 \mathrm{~kb}$ around the $A B C D 4$ gene detected a 

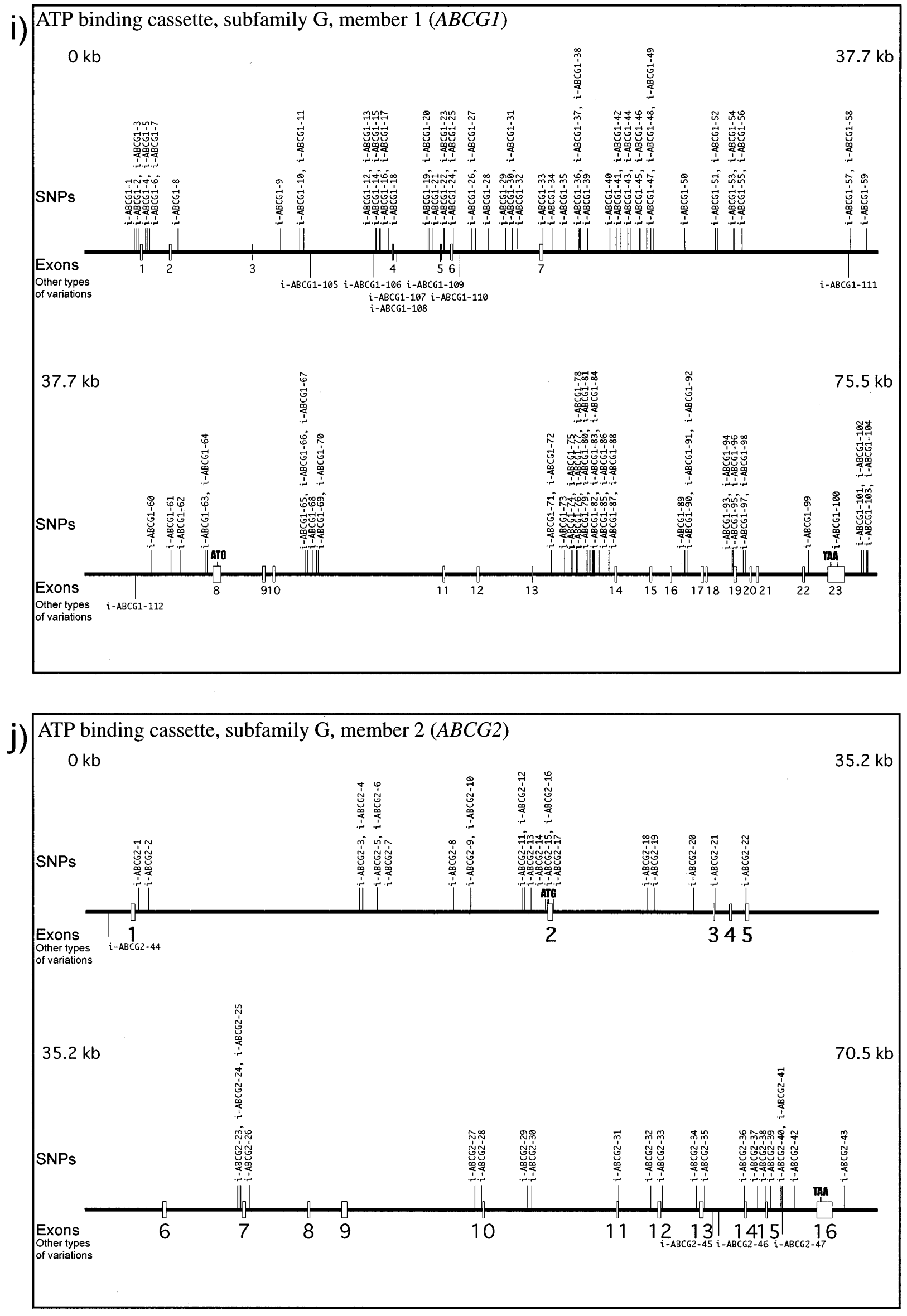

Fig. 1a-l. Continued 

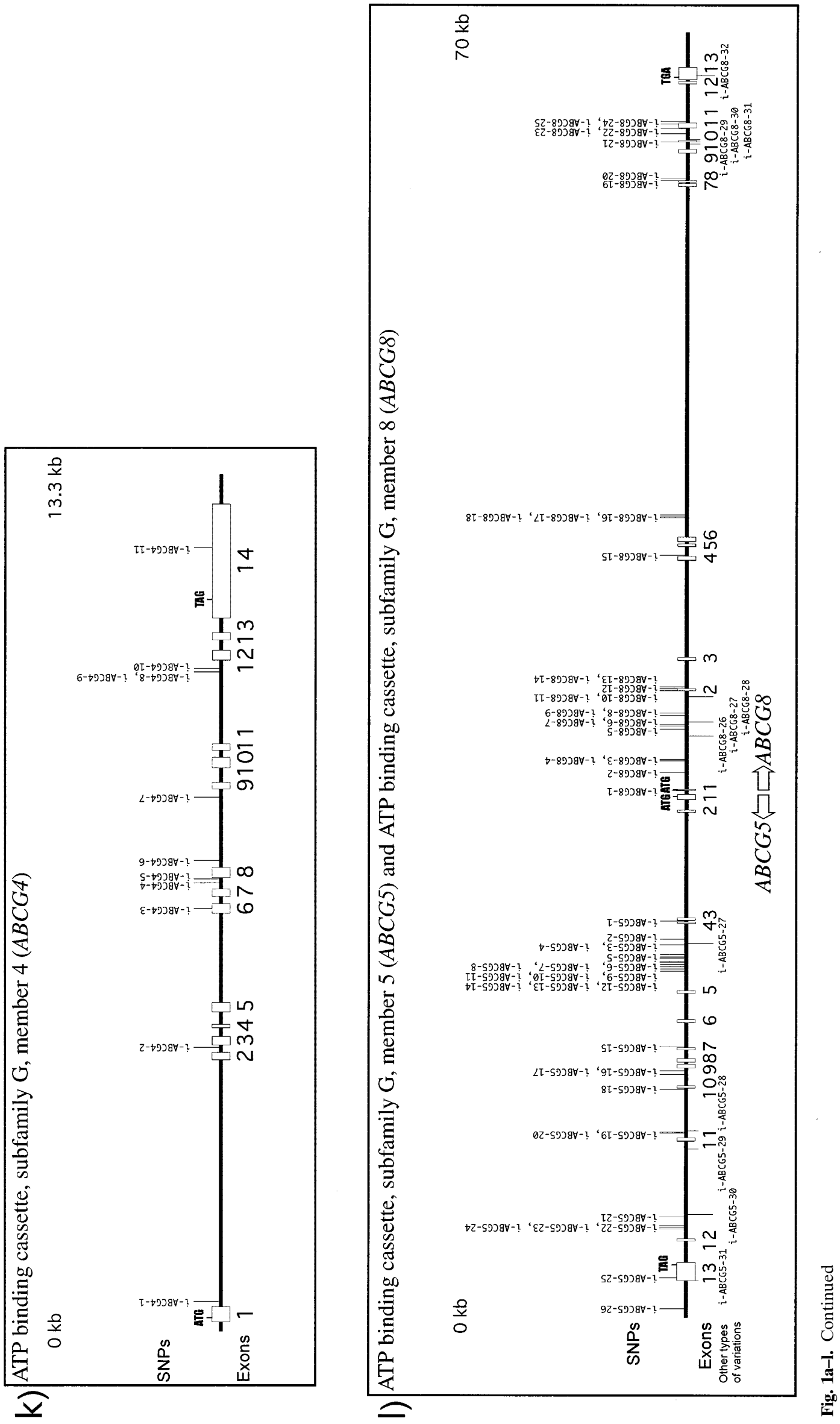


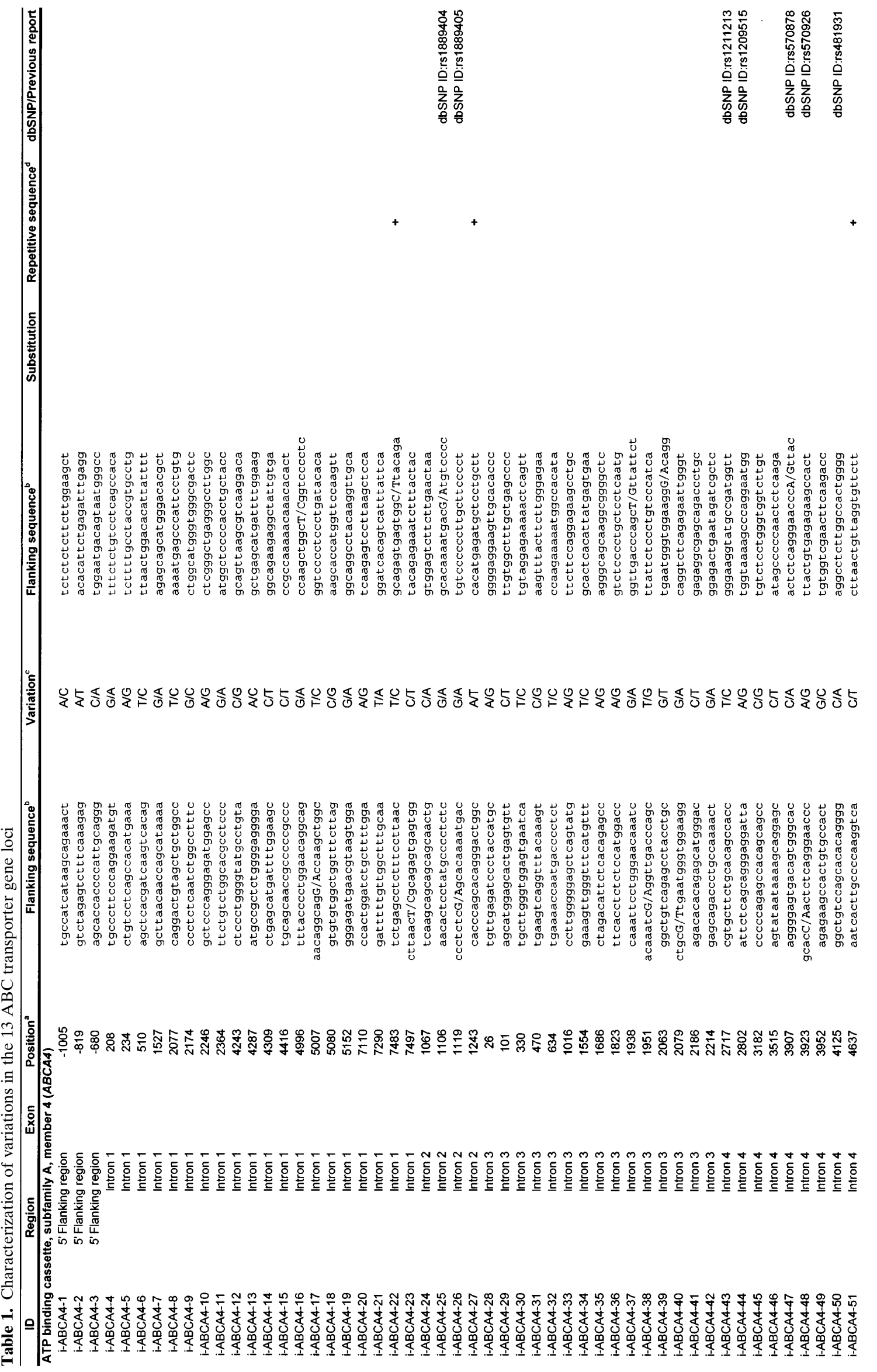




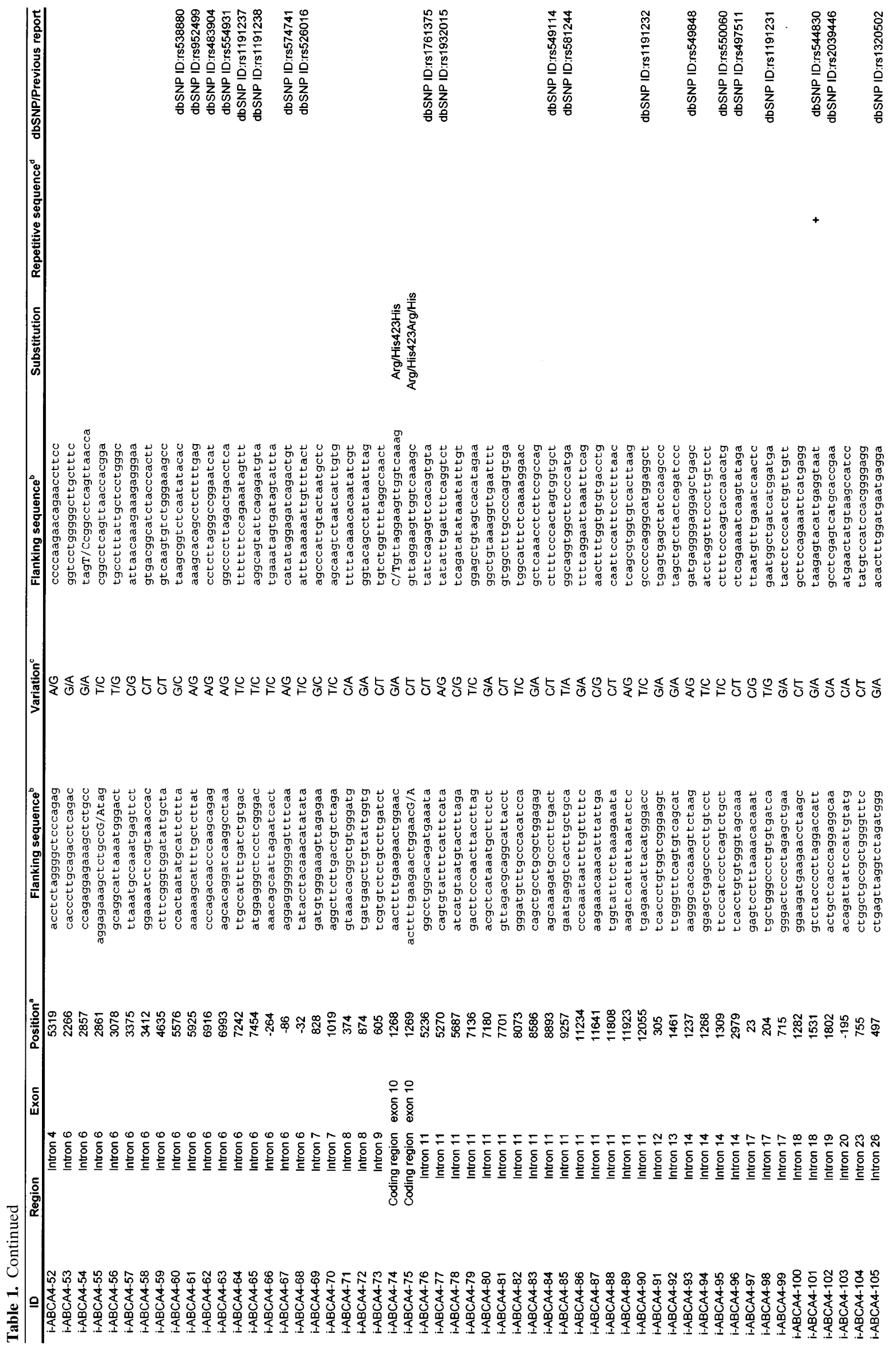




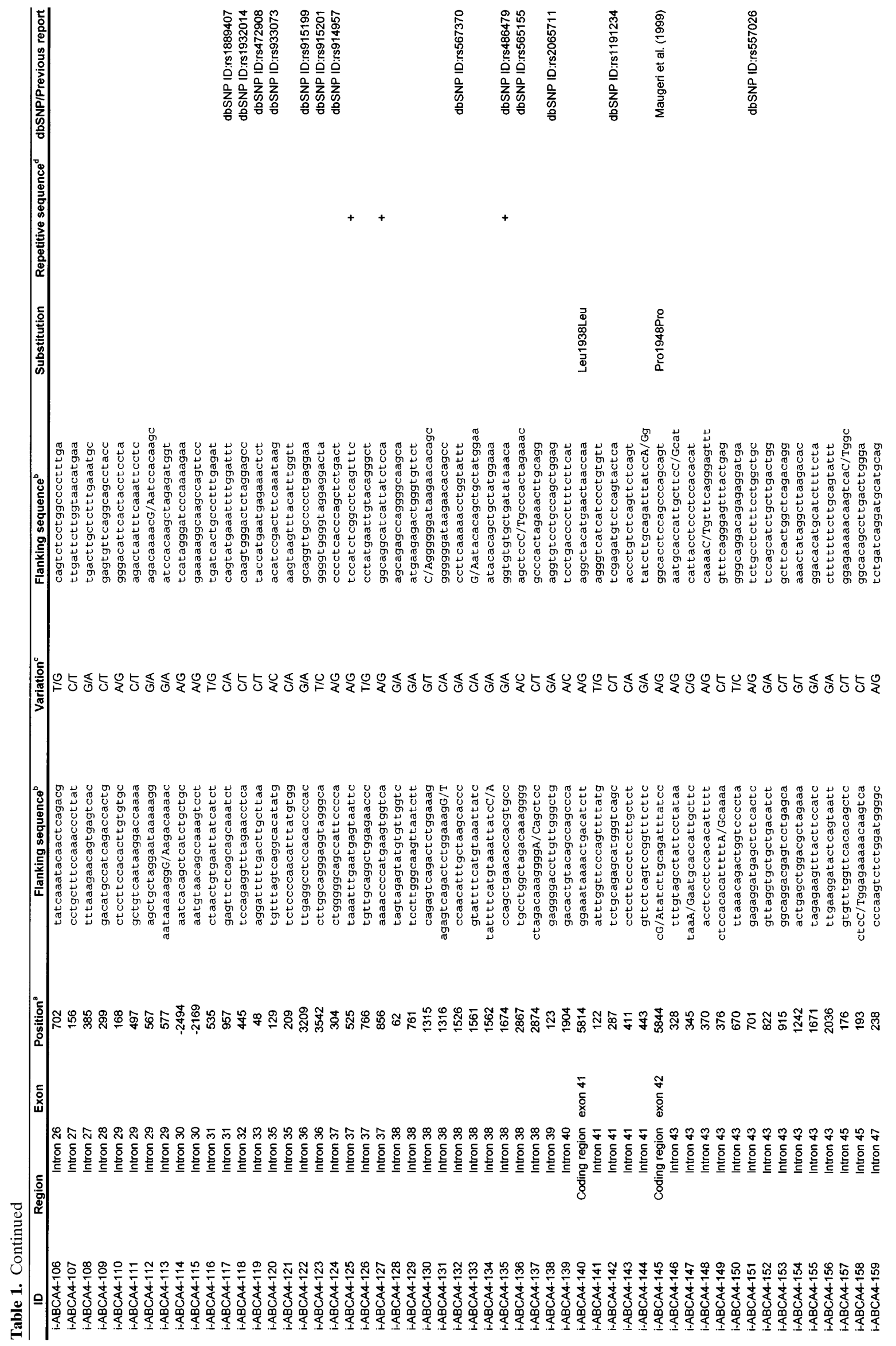




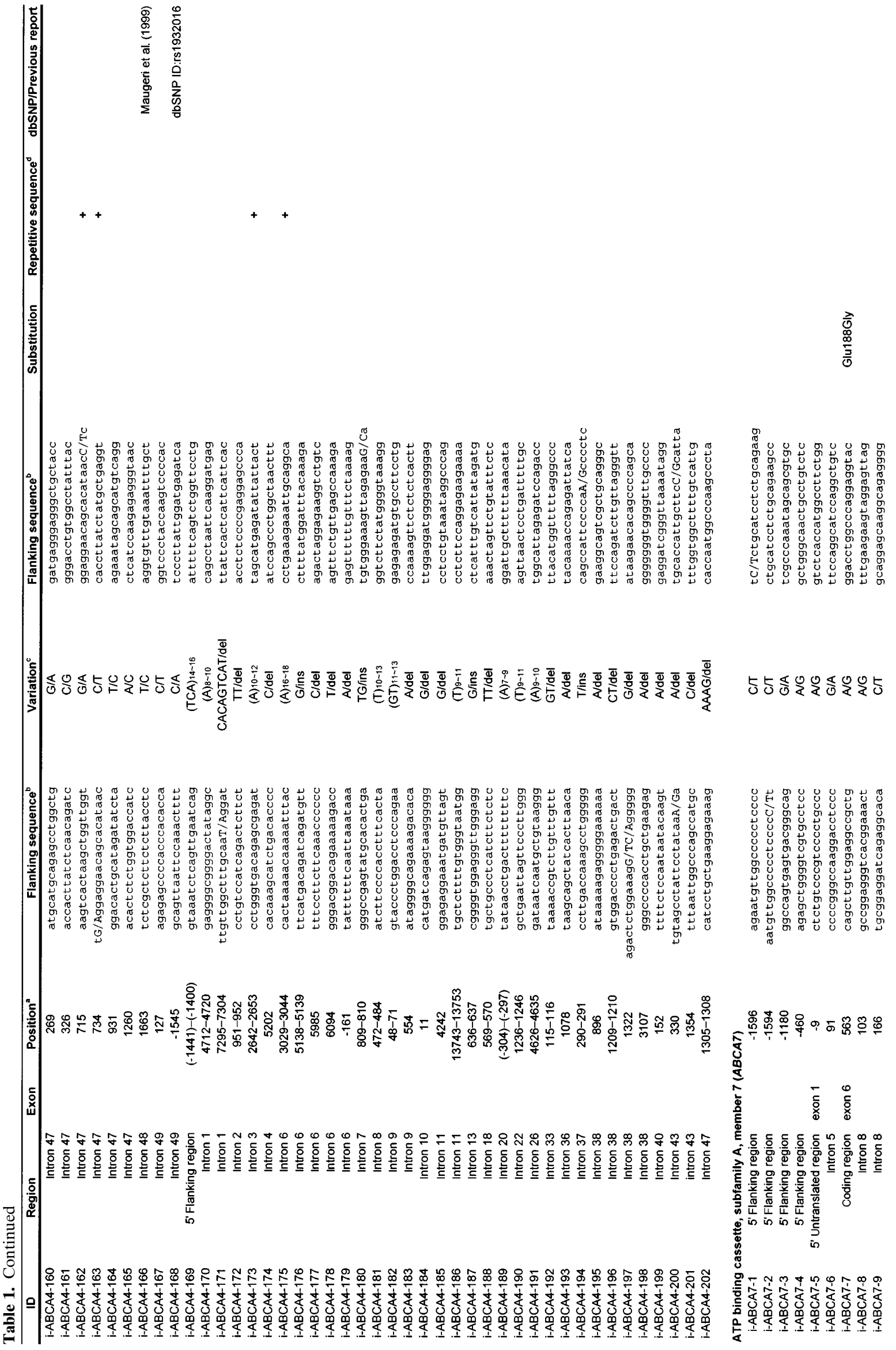




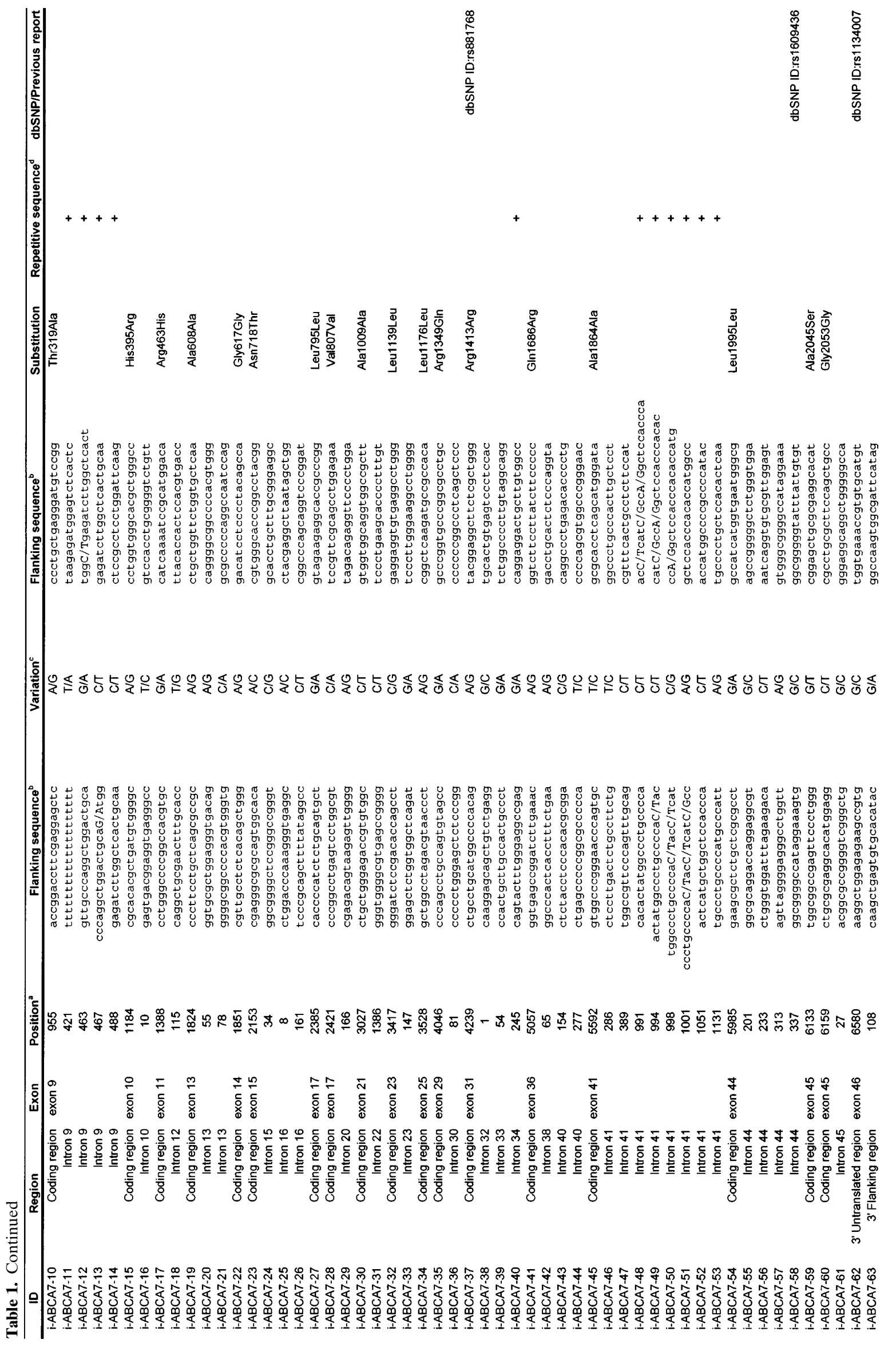




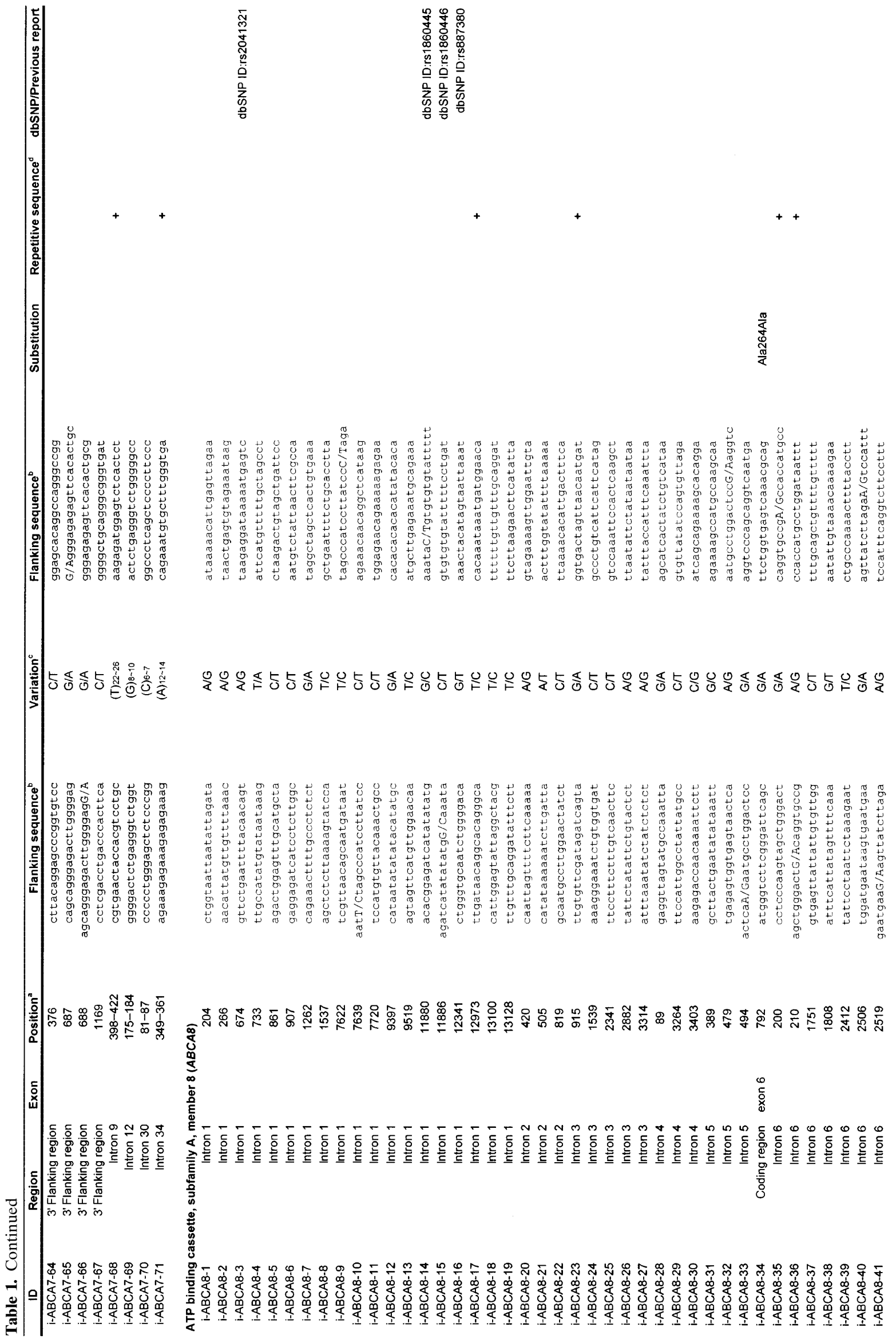




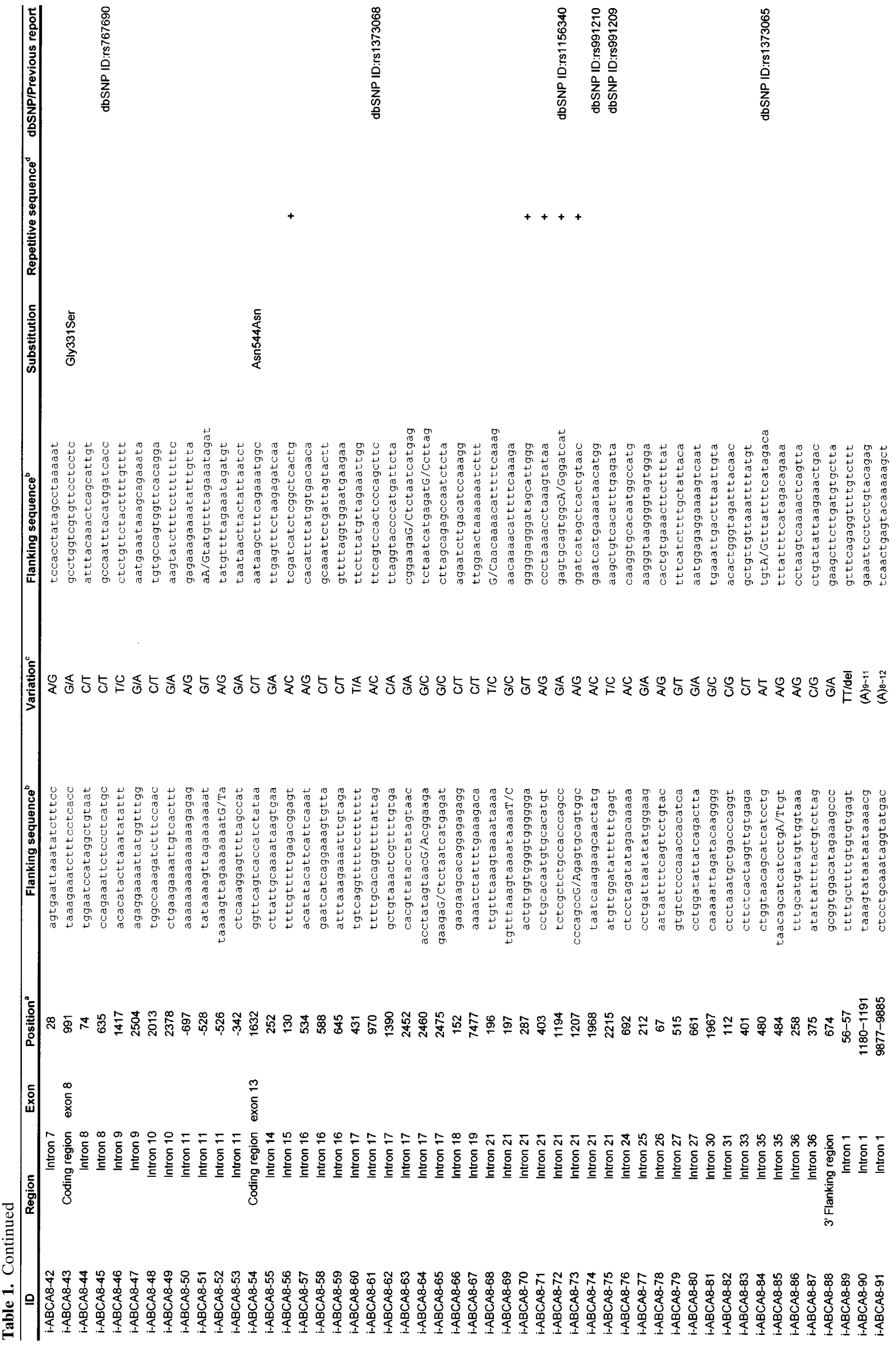




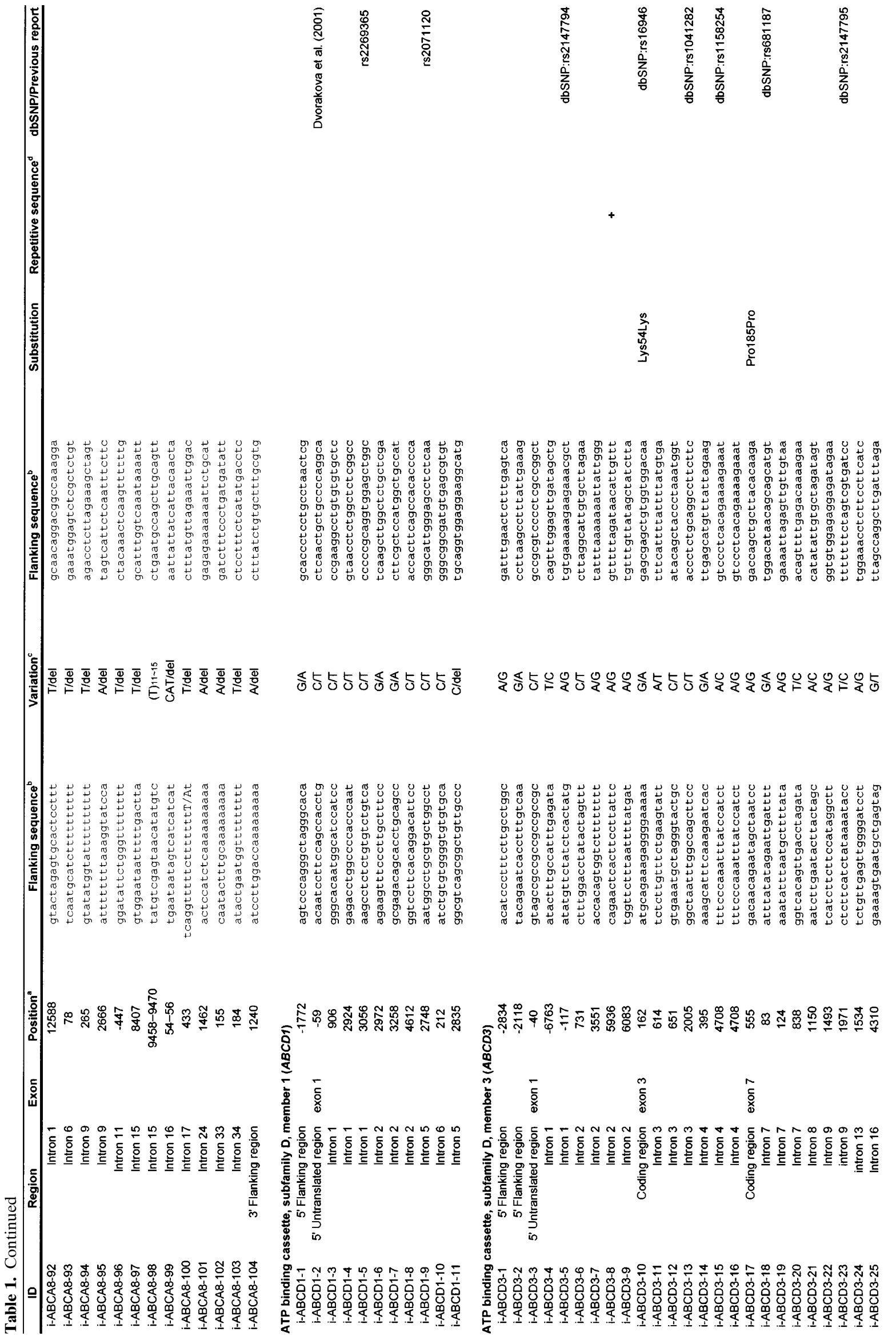




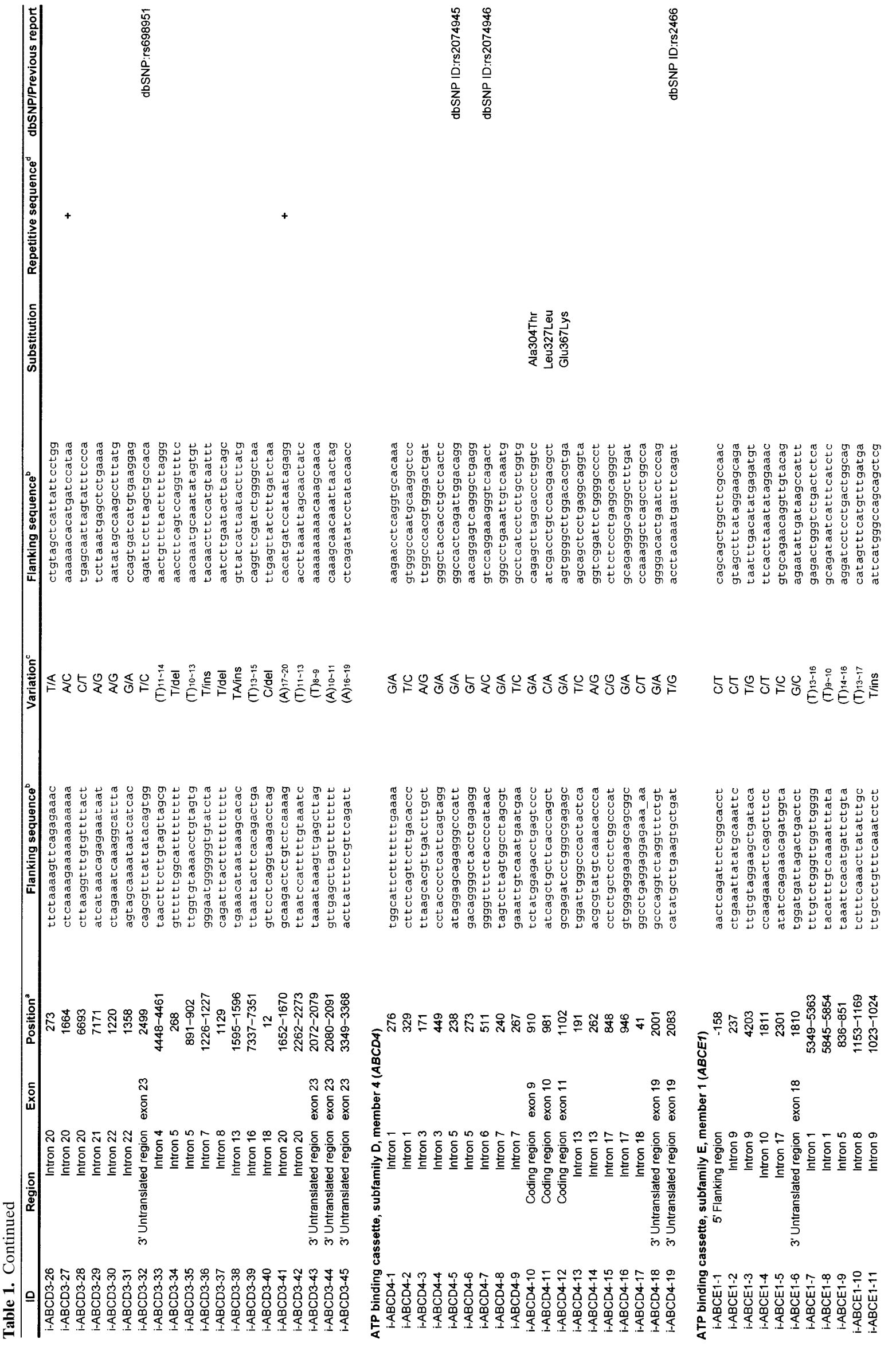




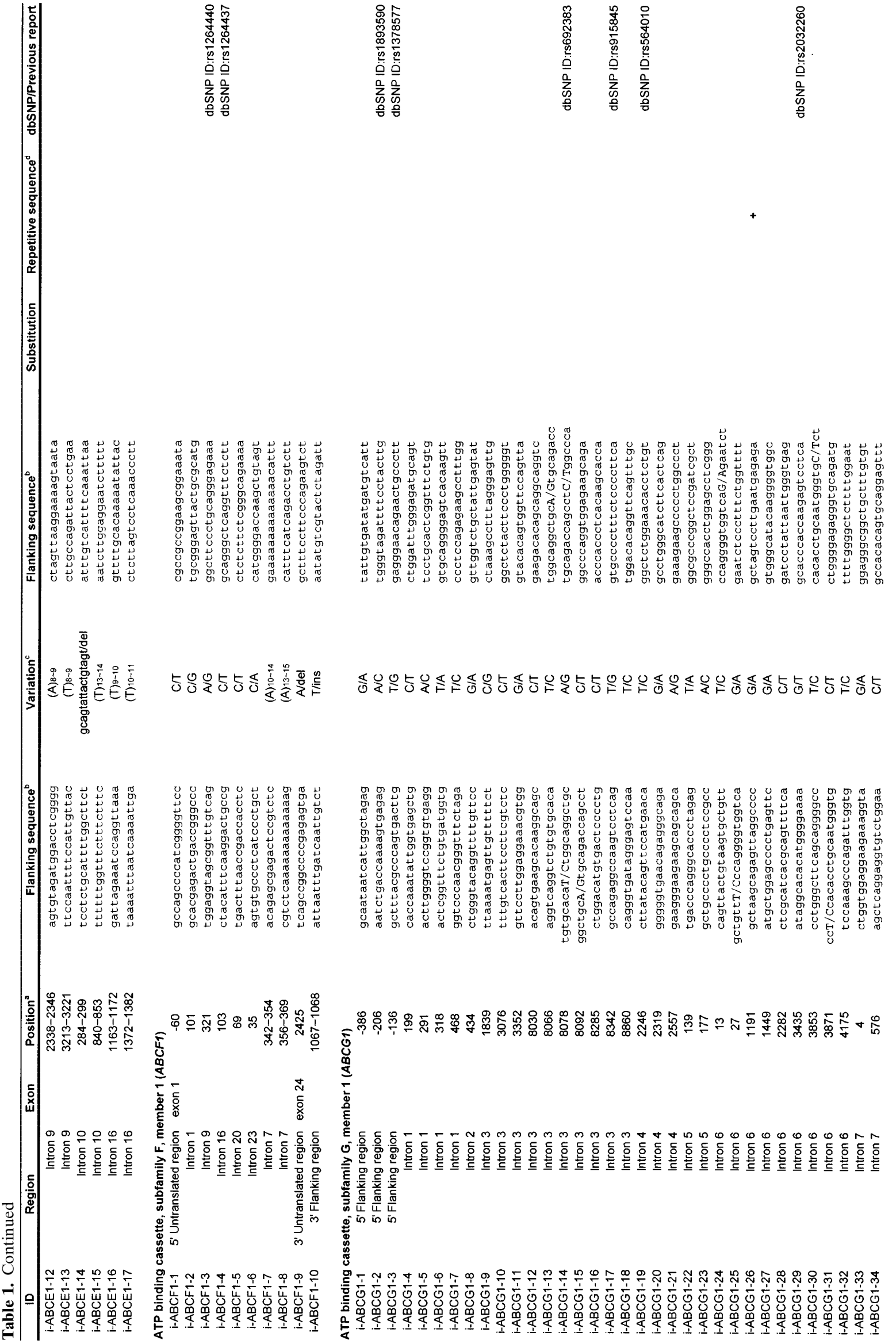




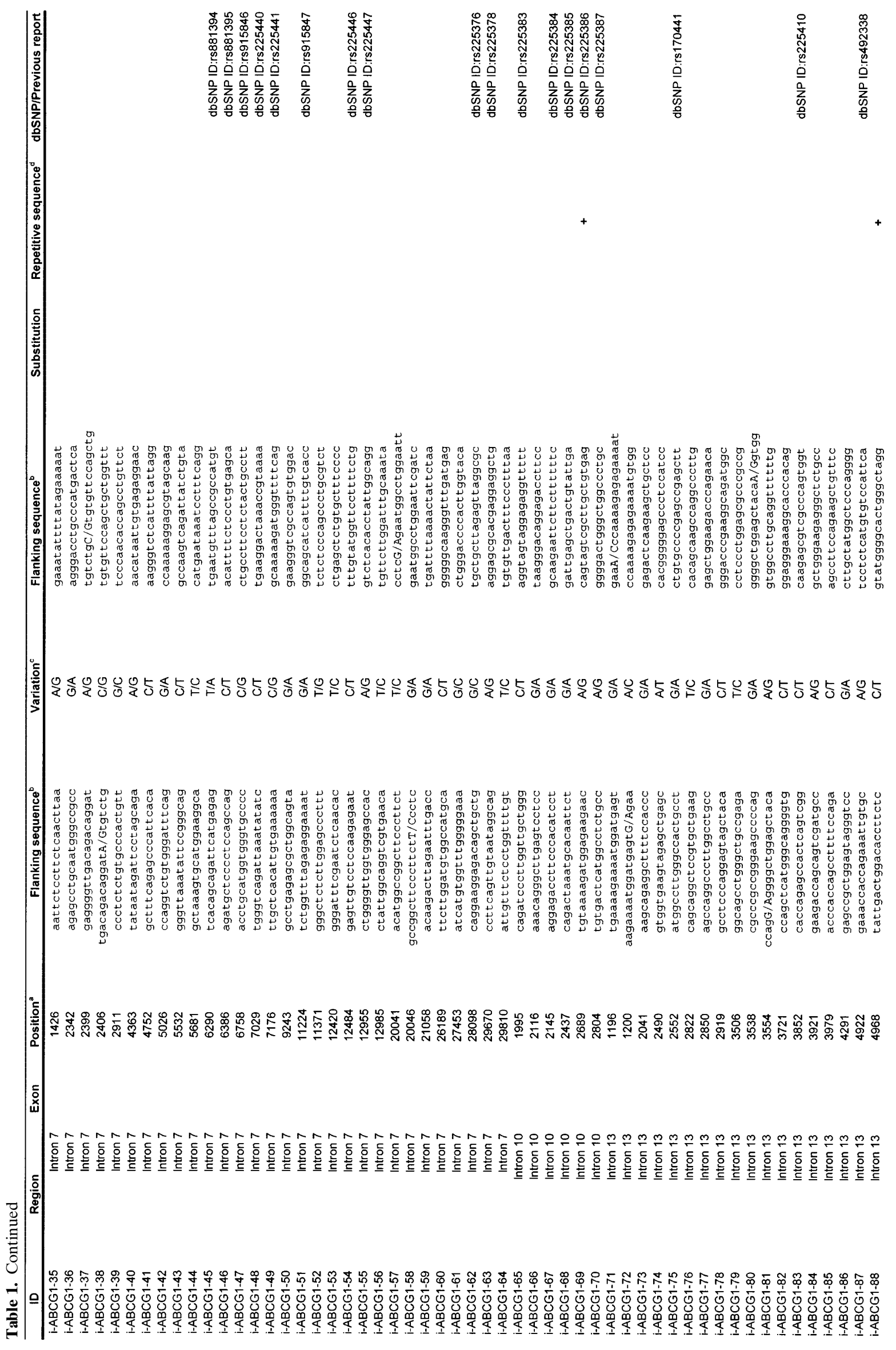




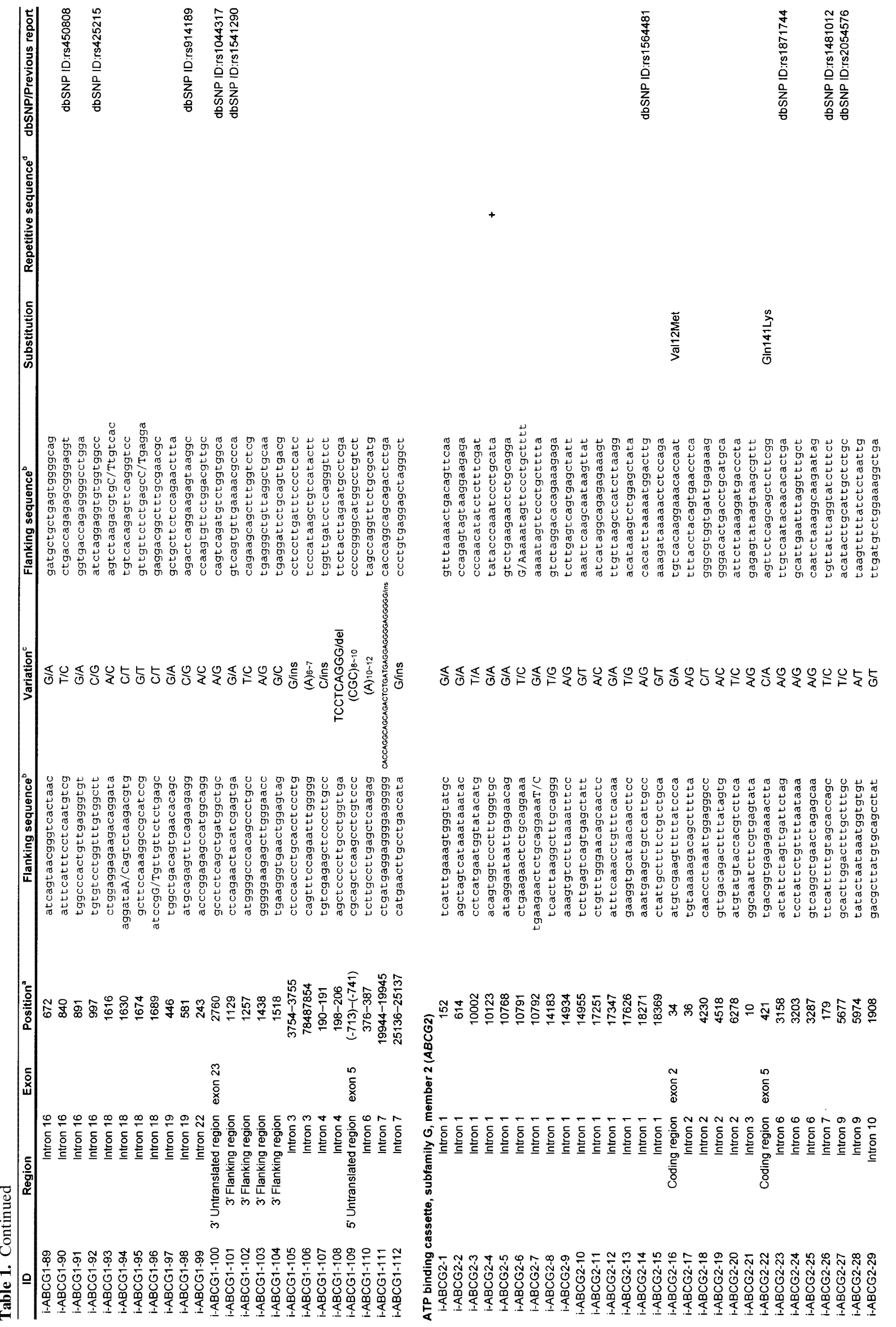




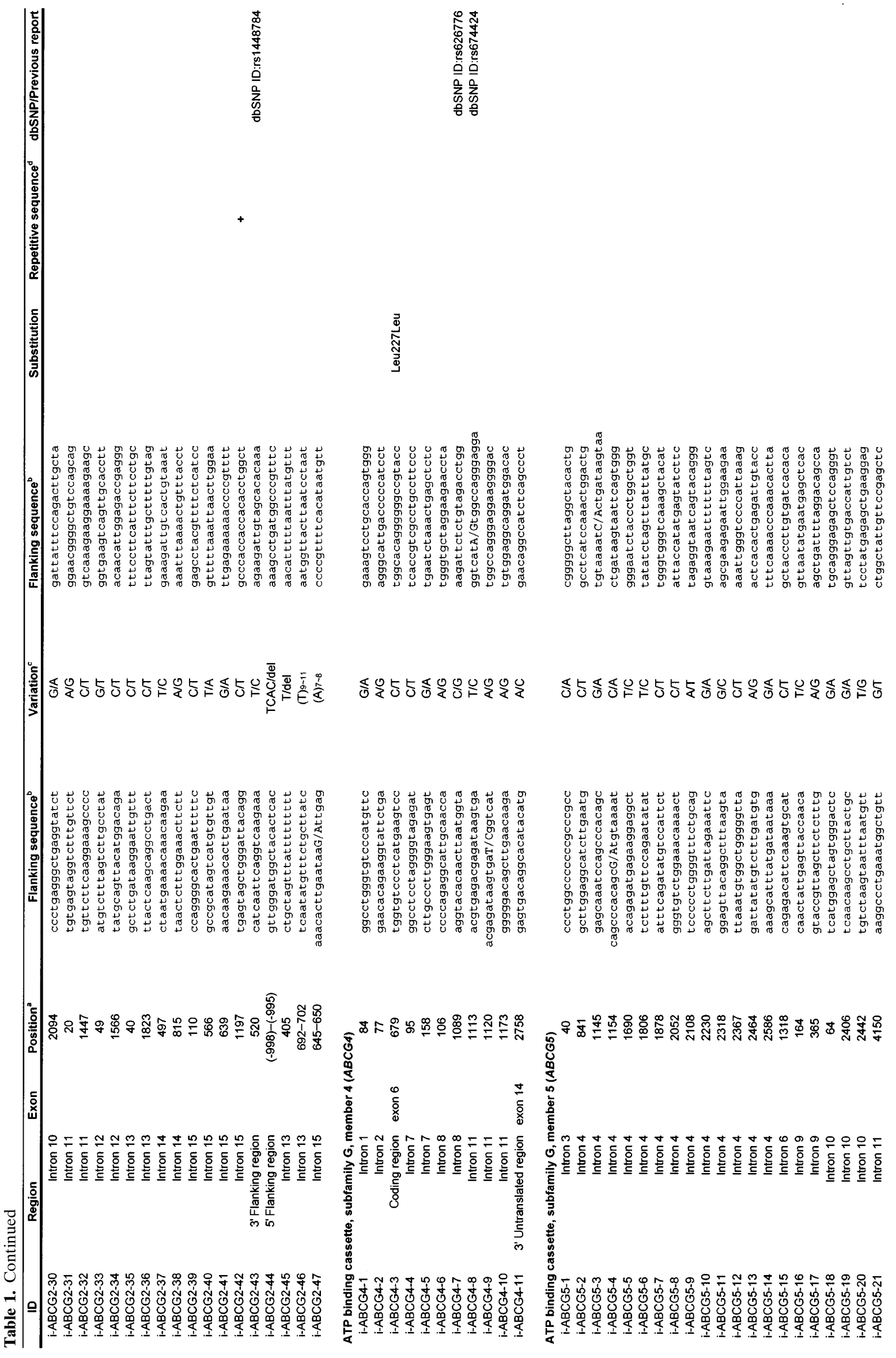




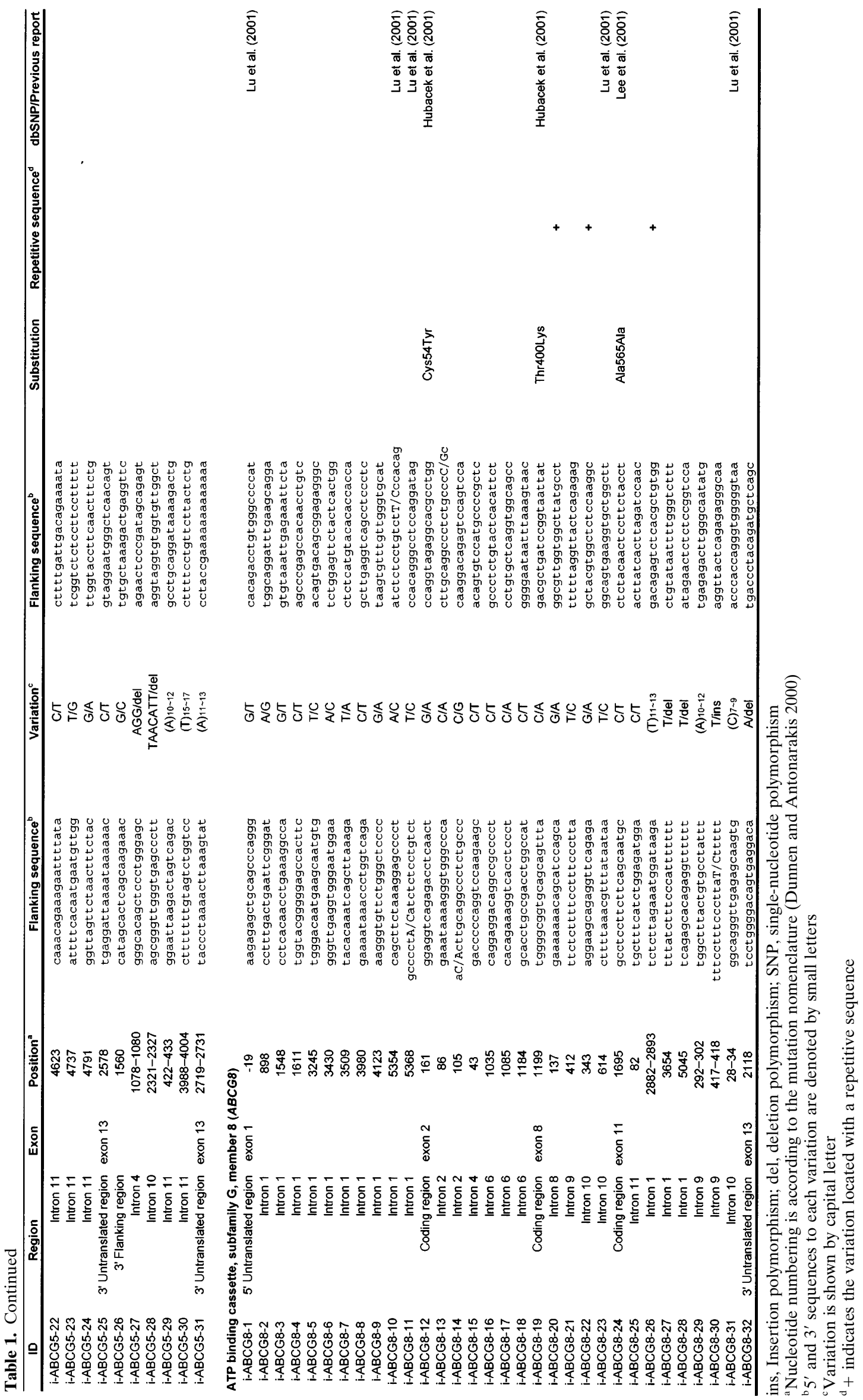


Table 2. Summary of genetic variations identified in $13 \mathrm{ABC}$ transporter genes

\begin{tabular}{|c|c|c|c|c|c|c|c|c|c|c|}
\hline Gene & $\begin{array}{l}5^{\prime} \text { flanking } \\
\text { region }\end{array}$ & $5^{\prime} \mathrm{UTR}^{\mathrm{a}}$ & $\begin{array}{l}\text { Coding } \\
\text { region }\end{array}$ & Intron & $3^{\prime} \mathrm{UTR}^{\mathrm{b}}$ & $\begin{array}{l}3^{\prime} \text { flanking } \\
\text { region }\end{array}$ & $\begin{array}{l}\text { Other types } \\
\text { of variations }\end{array}$ & SNP & $\begin{array}{l}\text { Identity to } \\
\text { dbSNP/previous } \\
\text { report }\end{array}$ & $\begin{array}{l}\text { New } \\
\text { SNP }\end{array}$ \\
\hline$A B C A 4$ & 3 & 0 & 4 & 161 & 0 & 0 & 34 & 168 & 43 & 125 \\
\hline$A B C A 7$ & 4 & 1 & 19 & 37 & 1 & 5 & 4 & 67 & 3 & 64 \\
\hline$A B C A 8$ & 0 & 0 & 3 & 84 & 0 & 1 & 16 & 88 & 10 & 78 \\
\hline$A B C D 1$ & 1 & 1 & 0 & 8 & 0 & 0 & 1 & 10 & 3 & 7 \\
\hline$A B C D 3$ & 2 & 1 & 2 & 26 & 1 & 0 & 13 & 32 & 7 & 25 \\
\hline$A B C D 4$ & 0 & 0 & 3 & 14 & 2 & 0 & 0 & 19 & 3 & 16 \\
\hline$A B C E 1$ & 1 & 0 & 0 & 4 & 1 & 0 & 11 & 6 & 0 & 6 \\
\hline$A B C F 1$ & 0 & 1 & 0 & 5 & 0 & 0 & 4 & 6 & 2 & 4 \\
\hline$A B C G 1$ & 3 & 0 & 0 & 96 & 1 & 4 & 8 & 104 & 29 & 75 \\
\hline$A B C G 2$ & 0 & 0 & 2 & 40 & 0 & 1 & 4 & 43 & 5 & 38 \\
\hline$A B C G 4$ & 0 & 0 & 1 & 9 & 1 & 0 & 0 & 11 & 2 & 9 \\
\hline$A B C G 5$ & 0 & 0 & 0 & 24 & 1 & 1 & 5 & 26 & 0 & 26 \\
\hline$A B C G 8$ & 0 & 1 & 3 & 21 & 0 & 0 & 7 & 25 & 7 & 18 \\
\hline Total & 14 & 5 & 37 & 529 & 8 & 12 & 107 & 605 & 114 & 491 \\
\hline
\end{tabular}

SNP, single-nucleotide polymorphism

${ }^{a} 5^{\prime}$ Untranslated region

' 3 ' Untranslated region

Table 3. Distribution of SNPs by types of nucleotide substitutions

\begin{tabular}{|c|c|c|c|c|c|c|c|}
\hline Gene & $\mathrm{A} / \mathrm{G}$ & $\mathrm{C} / \mathrm{T}$ & $\mathrm{A} / \mathrm{C}$ & $\mathrm{C} / \mathrm{G}$ & $\mathrm{G} / \mathrm{T}$ & $\mathrm{T} / \mathrm{A}$ & Total \\
\hline$A B C A 4$ & 67 & 54 & 19 & 14 & 10 & 4 & 168 \\
\hline$A B C A 7$ & 30 & 20 & 5 & 9 & 2 & 1 & 67 \\
\hline$A B C A 8$ & 36 & 29 & 5 & 9 & 5 & 4 & 88 \\
\hline$A B C D 1$ & 3 & 7 & 0 & 0 & 0 & 0 & 10 \\
\hline$A B C D 3$ & 17 & 9 & 3 & 0 & 1 & 2 & 32 \\
\hline$A B C D 4$ & 10 & 4 & 2 & 1 & 2 & 0 & 19 \\
\hline$A B C E 1$ & 0 & 4 & 0 & 1 & 1 & 0 & 6 \\
\hline$A B C F 1$ & 1 & 3 & 1 & 1 & 0 & 0 & 6 \\
\hline$A B C G 1$ & 41 & 38 & 6 & 10 & 5 & 4 & 104 \\
\hline$A B C G 2$ & 18 & 13 & 3 & 0 & 6 & 3 & 43 \\
\hline$A B C G 4$ & 6 & 3 & 1 & 1 & 0 & 0 & 11 \\
\hline$A B C G 5$ & 8 & 10 & 2 & 2 & 3 & 1 & 26 \\
\hline$A B C G 8$ & 5 & 11 & 5 & 1 & 2 & 1 & 25 \\
\hline Total & $242(40 \%)$ & $205(33.9 \%)$ & $52(8.6 \%)$ & $49(8.1 \%)$ & $37(6.1 \%)$ & $20(3.3 \%)$ & $605(100 \%)$ \\
\hline
\end{tabular}

SNP, Single-nucleotide polymorphism

total of 19 SNPs: 3 in coding regions, 14 in introns, and 2 in the $3^{\prime}$ untranslated region. The distribution of SNPs at this locus was 1 per $703 \mathrm{bp}$ on average. The frequency of each type of substitution was $52.6 \%$ for $\mathrm{A} / \mathrm{G}, 21.1 \%$ for $\mathrm{C} / \mathrm{T}$, $10.5 \%$ for $\mathrm{A} / \mathrm{C}, 5.3 \%$ for $\mathrm{C} / \mathrm{G}$, and $10.5 \%$ for $\mathrm{G} / \mathrm{T}$.

\section{$A B C E$ and $A B C F$ families}

The $A B C E$ and $A B C F$ subfamilies contain genes encoding peptides that include ATP-binding domains likely to be derived from ABC transporters but that have no transmembrane domains. Their functions in the membrane transport system are not well understood (Dean et al. 2001).

$A B C E 1$ locus. ABCE1, a 599-amino-acid protein, contains two ATP/GTP-binding motifs; it was originally identified as protein inhibitor RLI, which can regulate RNase L activity in the 2-5A pathway (Bisbal et al. 1995). Interferons induce transcription of numerous genes involved in defense against viral infections, in control of cell proliferation, and in differentiation, as well as in modulation of immune responses (Williams 1991). The 2-5A/RNase L system, one of the major pathways induced by interferons, might play a more general role in regulating RNA turnover and stability in cells (Hassel et al. 1993). RNase L is an endoribonuclease that, on activation by $2-5 \mathrm{~A}$, leads to inhibition of protein synthesis by cleaving mRNAs at the $3^{\prime}$ side of UpNp sequences (Floyd-Smith et al. 1981; Zhou et al. 1993).

Screening an approximately 26.2-kb region containing the $A B C E 1$ gene identified a total of six SNPs, 1 in the $5^{\prime}$ flanking region, 4 in introns, and 1 in the $3^{\prime}$ untranslated region. The distribution of SNPs at this locus was 1 per $4374 \mathrm{bp}$ on average. The frequency of each type of substitution was $66.7 \%$ for $\mathrm{C} / \mathrm{T}, 16.7 \%$ for $\mathrm{C} / \mathrm{G}$, and $16.7 \%$ for $\mathrm{G} / \mathrm{T}$. We also found 11 variations of other types at the $A B C E 1$ locus.

$A B C F 1$ locus. ABCF1 was first isolated as a protein of unknown function that was modulated by tumor necrosis 
factor alpha in cultured synoviocytes (Richard et al. 1998). The $A B C F 1$ cDNA encodes an 807-amino-acid peptide that contains two signature motifs of the $\mathrm{ABC}$ transporter family, a 2ATP/GTP-binding site A motif, and three nuclear localization signals. ABCF1 is likely to play a key role in the initiation of mRNA translation, through interaction with eukaryotic initiation factor 2 and association with ribosomes (Tyzack et al. 2000). Screening approximately $10.8 \mathrm{~kb}$ at the $A B C F 1$ locus identified a total of six SNPs, 1 in the $5^{\prime}$ untranslated region and 5 in introns; their distribution was 1 in $1795 \mathrm{bp}$, on average. The frequency of each type of substitution was $16.7 \%$ for $\mathrm{A} / \mathrm{G}, 50 \%$ for $\mathrm{C} / \mathrm{T}$, $16.7 \%$ for $\mathrm{A} / \mathrm{C}$, and $16.7 \%$ for $\mathrm{C} / \mathrm{G}$. We also found four variations of other types at this locus.

\section{$A B C G$ genes}

The ABCG subfamily is comprised of six 'reverse' halftransporters that have a nucleotide-binding fold at the amino terminus and a transmembrane domain at the carboxyl terminus.

$A B C G 1$ locus. One of the members in the ABCG subfamily, ABCG1, was originally named human White on the basis of $33 \%$ identity in amino-acid sequence to the product of the White gene of Drosophila melanogaster, which transports precursors of eye pigments, (guanine and tryptophan) along with brown and scarlet, in the eye cells of the fly (Chen et al. 1996; Croop et al. 1997; Klein et al. 1999; Dean et al. 2001). Klucken et al. (2000) showed that ABCG1 was regulated by cholesterol uptake or HDL3-mediated lipid release in human macrophages. Regulation of $A B C G 1$ mRNA levels by the liver-specific $X$ receptor/retinoid $X$ receptor pathway, which is involved in lipid metabolism (Repa et al. 2000; Venkateswaran et al. 2000), suggests a function for ABCG1 in homeostasis of cholesterol in macrophages. The $A B C G 1$ gene contains multiple promoters, spans more than $98 \mathrm{~kb}$ of genomic DNA, and consists of 23 exons that encode proteins with different amino-terminal sequences generated by alter-native splicing (Kennedy et al. 2001).

Screening an approximately $66.2-\mathrm{kb}$ region around the $A B C G 1$ gene identified a total of 104 SNPs: 3 in the 5' flanking region, 96 in introns, 1 in the $3^{\prime}$ untranslated region, and 4 in the $3^{\prime}$ flanking region. The distribution of SNPs at this locus was 1 per $637 \mathrm{bp}$ on average. The frequency of each type of substitution was $39.4 \%$ for $\mathrm{A} / \mathrm{G}, 36.5 \%$ for $\mathrm{C} / \mathrm{T}, 5.8 \%$ for $\mathrm{A} / \mathrm{C}, 9.6 \%$ for $\mathrm{C} / \mathrm{G}, 4.8 \%$ for $\mathrm{G} / \mathrm{T}$, and $3.8 \%$ for $\mathrm{T} / \mathrm{A}$. We also found eight variations of other types at the $A B C G 1$ locus.

$A B C G 2$ locus. $A B C G 2$, the second member of the $\mathrm{ABC}$ transporter subfamily $\mathrm{G}$, is also known as the placental $\mathrm{ABC}$ transporter, breast-cancer resistance protein, or mitoxantrone resistance-associated protein (Allikmets et al. 1998; Doyle et al. 1998; Miyake et al. 1999). ABCG2 is often amplified and overexpressed in human cancer cells and is capable of mediating drug resistance even in the absence of multidrug resistance proteins MDR1 and MRP1 (Litman et al. 2000; Robey et al. 2001). Screening $29.1 \mathrm{~kb}$ at the $A B C G 2$ gene locus identified a total of 43 SNPs, 2 of them in coding regions, 40 in introns, and 1 in the $3^{\prime}$ flanking region. The distribution of SNPs at this locus was 1 per 676 $\mathrm{bp}$ on average. The frequency of each type of substitution was $41.9 \%$ for $\mathrm{A} / \mathrm{G}, 30.2 \%$ for $\mathrm{C} / \mathrm{T}, 7.0 \%$ for $\mathrm{A} / \mathrm{C}, 14.0 \%$ for $\mathrm{G} / \mathrm{T}$, and $7.0 \%$ for T/A. We also found four variations of other types at the $A B C G 2$ locus.

$A B C G 4$ locus. The $A B C G 4$ gene on chromosome $11 \mathrm{q} 23.3$ consists of 14 exons spanning $12.6 \mathrm{~kb}$ of genomic DNA; the 3.5-kb transcript encodes a 646-amino-acid peptide (Engel et al. 2001). This half-size ABC transporter possesses a nucleotide-binding fold followed by a cluster of six transmembrane-spanning domains, and is thought to function in cholesterol transport. Screening an approximately $8.2-\mathrm{kb}$ region at the $A B C G 4$ gene locus identified a total of 11 SNPs, 1 in a coding region, 9 in introns, and 1 in the 3' untranslated region. The distribution of SNPs at this locus was 1 per $748 \mathrm{bp}$ on average. The frequency of each type of substitution was 54.6 for $\mathrm{A} / \mathrm{G}, 27.2$ for $\mathrm{C} / \mathrm{T}, 9.1 \%$ for $\mathrm{A} / \mathrm{C}$, and $9.1 \%$ for $\mathrm{C} / \mathrm{G}$.

$A B C G 5$ and $A B C G 8$ loci. The $A B C G 5$ and $A B C G 8$ genes encode proteins of 651 and 673 amino acids, respectively, which share $28 \%$ identity. Both proteins contain an $\mathrm{N}$ terminal ATP-binding motif (Walker A and B motifs), an $\mathrm{ABC}$ transporter signature motif, and six transmembrane segments in the terminus. Several mutations in the $A B C G 8$ gene and one mutation in the $A B C G 5$ gene have been found in patients with sitosterolemia (Berge et al. 2000). The two genes are located in close proximity, in a headto-head configuration on chromosome $2 \mathrm{p} 21$. Screening an approximately $15.7-\mathrm{kb}$ region at the $A B C G 5$ gene locus identified a total of 26 SNPs, 24 of them intronic, 1 in the $3^{\prime}$ untranslated region, and 1 in the $3^{\prime}$ flanking region. The distribution of SNPs at this locus was 1 per $603 \mathrm{bp}$ on average. The frequency of each type of substitution at the $A B C G 5$ locus was $30.8 \%$ for $\mathrm{A} / \mathrm{G}, 38.5 \%$ for $\mathrm{C} / \mathrm{T}$, $7.7 \%$ for $\mathrm{A} / \mathrm{C}, 7.7 \%$ for $\mathrm{C} / \mathrm{G}, 11.5 \%$ for $\mathrm{G} / \mathrm{T}$, and $3.8 \%$ for T/A. We also found five variations of other types at this locus.

Screening an approximately $31.2-\mathrm{kb}$ region around the $A B C G 8$ gene identified a total of 25 SNPs: 1 in the $5^{\prime}$ untranslated region, 3 in coding regions, and 21 in introns. The distribution of SNPs at this locus was 1 per $1249 \mathrm{bp}$ on average, and their frequencies were $20.0 \%$ for $\mathrm{A} / \mathrm{G}, 44.0 \%$ for $\mathrm{C} / \mathrm{T}, 20.0 \%$ for $\mathrm{A} / \mathrm{C}, 4.0 \%$ for $\mathrm{C} / \mathrm{G}, 8.0 \%$ for $\mathrm{G} / \mathrm{T}$, and $4.0 \%$ for $\mathrm{T} / \mathrm{A}$. We also found seven variations of other types at the $A B C G 8$ locus.

Altogether we have collected a total of 712 variations, including 605 SNPs and 107 variations of other types, among 13 genes encoding $\mathrm{ABC}$ transporters in a 96chromosome sample from the Japanese population. The SNP collection reported here provides genetic data that should be helpful for personalized medical services and also for identifying alleles involved in drug efficacy, side effects, and/or complex genetic diseases. 


\section{References}

Allikmets R, Gerrard B, Hutchinson A, Dean M (1996) Characterization of the human $\mathrm{ABC}$ superfamily: isolation and mapping of 21 new genes using the expressed sequence tags database. Hum Mol Genet 5:1649-1655

Allikmets $\mathrm{R}$, Singh $\mathrm{N}$, Sun $\mathrm{H}$, Shroyer NF, Hutchinson A, Chidambaram A, Gerrard B, Baird L, Stauffer D, Peiffer A, Rattner A, Smallwood P, Li Y, Anderson KL, Lewis RA, Nathans J, Leppert M, Dean M, Lupski JR (1997) A photoreceptor cell-specific ATPbinding transporter gene $(A B C R)$ is mutated in recessive Stargardt macular dystrophy. Nat Genet 15:236-246

Allikmets R, Schriml LM, Hutchinson A, Romano-Spica V, Dean M (1998) A human placenta-specific ATP-binding cassette gene $(A B C P)$ on chromosome $4 \mathrm{q} 22$ that is involved in multidrug resistance. Cancer Res 58:5337-5339

Berge KE, Tian H, Graf GA, Yu L, Grishin NV, Schultz J, Kwiterovich P, Shan B, Barnes R, Hobbs HH (2000) Accumulation of dietary cholesterol in sitosterolemia caused by mutations in adjacent ABC transporters. Science 290:1771-1775

Bisbal C, Martinand C, Silhol M, Lebleu B, Salehzada T (1995) Cloning and characterization of a RNAse $\mathrm{L}$ inhibitor. A new component of the interferon-regulated 2-5A pathway. J Biol Chem 270:1330813317

Broccardo C, Luciani M, Chimini G (1999) The ABCA subclass of mammalian transporters. Biochim Biophys Acta 1461:395-404

Chen H, Rossier C, Lalioti MD, Lynn A, Chakravarti A, Perrin G, Antonarakis SE (1996) Cloning of the cDNA for a human homologue of the Drosophila white gene and mapping to chromosome 21q22.3. Am J Hum Genet 59:66-75

Croop JM, Tiller GE, Fletcher JA, Lux ML, Raab E, Goldenson D, Son D, Arciniegas S, Wu RL (1997) Isolation and characterization of a mammalian homolog of the Drosophila white gene. Gene 185:7785

Dean M, Rzhetsky A, Allikmets R (2001) The human ATP-binding cassette (ABC) transporter superfamily. Genome Res 11:1156-1166

Dodd A, Rowland SA, Hawkes SL, Kennedy MA, Love DR (1997) Mutations in the adrenoleukodystrophy gene. Hum Mutat 9:500-511

Doyle LA, Yang W, Abruzzo LV, Krogmann T, Gao Y, Rishi AK, Ross DD (1998) A multidrug resistance transporter from human MCF-7 breast cancer cells. Proc Natl Acad Sci USA 95:15665-15670

Dunnen JT, Antonarakis SE (2000) Mutation nomenclature extensions and suggestions to describe complex mutations: a discussion. Hum Mutat 15:7-12

Dvorakova L, Storkanova G, Unterrainer G, Hujova J, Kmoch S, Zeman J, Hrebicek M, Berger J (2001) Eight novel $A B C D 1$ gene mutations and three polymorphisms in patients with $\mathrm{X}$-linked adrenoleukodystrophy: the first polymorphism causing an amino acid exchange. Hum Mutat 18:52-60

Engel T, Lorkowski S, Lueken A, Rust S, Schluter B, Berger G, Cullen P, Assmann G (2001) The human ABCG4 gene is regulated by oxysterols and retinoids in monocyte-derived macrophages. Biochem Biophys Res Commun 288:483-488

Floyd-Smith G, Slattery E, Lengyel P (1981) Interferon action: RNA cleavage pattern of a $\left(2^{\prime}-5^{\prime}\right)$ oligoadenylate-dependent endonuclease. Science 212:1030-1032

Gartner J, Moser H, Valle D (1992) Mutations in the 70K peroxisomal membrane protein gene in Zellweger syndrome. Nat Genet 1:16-23

Gray IC, Campbell DA, Spurr NK (2000) Single nucleotide polymorphisms as tools in human genetics. Hum Mol Genet 9:2403-2408

Hassel BA, Zhou A, Sotomayor C, Maran A, Silverman RH (1993) A dominant negative mutant of 2-5A-dependent RNase suppresses antiproliferative and antiviral effects of interferon. EMBO J $12: 3297-3304$

Holzinger A, Kammerer S, Roscher AA (1997) Primary structure of human PMP69, a putative peroxisomal ABC-transporter. Biochem Biophys Res Commun 237:152-157

Hubacek JA, Berge KE, Cohen JC, Hobbs HH (2001) Mutations in ATP-cassette binding proteins G5 (ABCG5) and G8 (ABCG8) causing sitosterolemia. Hum Mutat 18:359-360

Iida A, Sekine A, Saito S, Kitamura Y, Kitamoto T, Osawa S, Mishima C, Nakamura Y (2001a) Catalog of 320 single nucleotide polymorphisms (SNPs) in 20 oxidoreductase and sulfotransferae genes. J Hum Genet 46:225-240
Iida A, Saito S, Sekine A, Kitamoto T, Kitamura Y, Mishima C, Osawa S, Kondo K, Harigae S, Nakamura Y (2001b) Catalog of 434 single nucleotide polymorphisms (SNPs) in the alcohol dehydrogenase genes, glutathione S transferase genes, and NADH ubiquinone oxidoreductase genes. J Hum Genet 46:385-407

Iida A, Saito S, Sekine A, Kitamura Y, Kondo K, Mishima C, Osawa S, Harigae S, Nakamura Y (2001c) High-density single-nucleotide polymorphism (SNP) map of the $150-\mathrm{kb}$ region corresponding to the human ATP-binding cassette transporter A1 ( $A B C A 1)$ gene. J Hum Genet 46:522-528

Iida A, Saito S, Sekine A, Harigae S, Osawa S, Mishima C, Kondo K, Kitamura Y, Nakamura Y (2001d) Catalog of 46 single-nucleotide polymorphisms (SNPs) in the microsomal glutathione S-transferase 1 (MGST1) gene. J Hum Genet 46:590-594

Iida A, Saito S, Sekine A, Mishima C, Kondo K, Kitamura Y, Harigae S, Osawa S, Nakamura Y (2001e) Catalog of 258 single-nucleotide polymorphisms (SNPs) in genes encoding three organic anion transporters, three organic anion-transporting polypeptides, and three NADH:ubiquinone oxidoreductase flavoproteins. J Hum Genet 46:668-683

Iida A, Saito S, Sekine A, Mishima C, Kitamura Y, Kondo K, Harigae S, Osawa S, Nakamura Y (2002a) Catalog of 77 single-nucleotide polymorphisms (SNPs) in the carbohydrate sulfotransferase 1 (CHST1) and carbohydrate sulfotransferase 3 (CHST3) genes. J Hum Genet 47:14-19

Iida A, Saito S, Sekine A, Kondo K, Mishima C, Kitamura Y, Harigae S, Osawa S, Nakamura Y (2002b) Thirteen single-nucleotide polymorphisms (SNPs) in the alcohol dehydrogenase 4 (ADH4) gene locus. J Hum Genet 47:74-76

Kaminski WE, Orso E, Diederich W, Klucken J, Drobnik W, Schmitz G (2000) Identification of a novel human sterol-sensitive ATPbinding cassette transporter (ABCA7). Biochem Biophys Res Commun 273:532-538

Kennedy MA, Venkateswaran A, Tarr PT, Xenarios I, Kudoh J, Shimizu N, Edwards PA (2001) Characterization of the human $A B C G 1$ gene: liver $\mathrm{X}$ receptor activates an internal promoter that produces a novel transcript encoding an alternative form of the protein. J Biol Chem 276:39438-39447

Klein I, Sarkadi B, Varadi A (1999) An inventory of the human ABC proteins. Biochim Biophys Acta 1461:237-262

Klucken J, Buchler C, Orso E, Kaminski WE, Porsch-Ozcurumez M, Liebisch G, Kapinsky M, Diederich W, Drobnik W, Dean M, Allikmets R, Schmitz G (2000) ABCG1 (ABC8), the human homolog of the Drosophila white gene, is a regulator of macrophage cholesterol and phospholipid transport. Proc Natl Acad Sci USA 97:817-822

Lee MH, Lu K, Patel SB (2001) Genetic basis of sitosterolemia. Curr Opin Lipidol 12:141-149

Litman T, Brangi M, Hudson E, Fetsch P, Abati A, Ross DD, Miyake K, Resau JH, Bates SE (2000) The multidrug-resistant phenotype associated with overexpression of the new ABC half-transporter, MXR (ABCG2). J Cell Sci 113:2011-2021

Lu K, Lee MH, Hazard S, Brooks-Wilson A, Hidaka H, Kojima H, Ose L, Stalenhoef AF, Mietinnen T, Bjorkhem I, Bruckert E, Pandya A, Brewer HB Jr, Salen G, Dean M, Srivastava A, Patel SB (2001) Two genes that map to the STSL locus cause sitosterolemia: genomic structure and spectrum of mutations involving sterolin-1 and sterolin-2, encoded by $A B C G 5$ and $A B C G 8$, respectively. Am J Hum Genet 69:278-290

Maugeri A, van Driel MA, van de Pol DJ, Klevering BJ, van Haren FJ, Tijmes N, Bergen AA, Rohrschneider K, Blankenagel A, Pinckers AJ, Dahl N, Brunner HG, Deutman AF, Hoyng CB, Cremers FP (1999) The $2588 \mathrm{G} \rightarrow \mathrm{C}$ mutation in the $A B C R$ gene is a mild frequent founder mutation in the Western European population and allows the classification of $A B C R$ mutations in patients with Stargardt disease. Am J Hum Genet 64:1024-1035

McCarthy JJ, Hilfiker R (2000) The use of single-nucleotide polymorphism maps in pharmacogenomics. Nat Biotechnol 18:505-508

Meyer UA (2000) Pharmacogenetics and adverse drug reactions. Lancet 356:1667-1671

Miyake K, Mickley L, Litman T, Zhan Z, Robey R, Cristensen B, Brangi M, Greenberger L, Dean M, Fojo T, Bates SE (1999) Molecular cloning of cDNAs which are highly overexpressed in mitoxantrone-resistant cells: demonstration of homology to $A B C$ transport genes. Cancer Res 59:8-13 
Mosser J, Douar AM, Sarde CO, Kioschis P, Feil R, Moser H, Poustka AM, Mandel JL, Aubourg P (1993) Putative X-linked adrenoleukodystrophy gene shares unexpected homology with ABC transporters. Nature 361:726-730

Nagase T, Ishikawa K, Suyama M, Kikuno R, Hirosawa M, Miyajima N, Tanaka A, Kotani H, Nomura N, Ohara O (1998) Prediction of the coding sequences of unidentified human genes. XII. The complete sequences of 100 new cDNA clones from brain which code for large proteins in vitro. DNA Res 5:355-364

Nickerson DA, Tobe VO, Taylor SL (1997) PolyPhred: automating the detection and genotyping of single nucleotide substitutions using fluorescence-based resequencing. Nucleic Acids Res 25:27452751

Repa JJ, Turley SD, Lobaccaro JA, Medina J, Li L, Lustig K, Shan B, Heyman RA, Dietschy JM, Mangelsdorf DJ (2000) Regulation of absorption and ABC1-mediated efflux of cholesterol by RXR heterodimers. Science 289:1524-1529

Richard M, Drouin R, Beaulieu AD (1998) ABC50, a novel human ATP-binding cassette protein found in tumor necrosis factoralpha-stimulated synoviocytes. Genomics 53:137-145

Robey RW, Medina-Perez WY, Nishiyama K, Lahusen T, Miyake K, Litman T, Senderowicz AM, Ross DD, Bates SE (2001) Overexpression of the ATP-binding cassette half-transporter, ABCG2 (Mxr/BCrp/ABCP1), in flavopiridol-resistant human breast cancer cells. Clin Cancer Res 7:145-152

Roses AD (2000) Pharmacogenetics and the practice of medicine. Nature 405:857-865

Sachidanandam R, Weissman D, Schmidt SC, Kakol JM, Stein LD, Marth G, Sherry S, Mullikin JC, Mortimore BJ, Willey DL, Hunt SE, Cole CG, Coggill PC, Rice CM, Ning Z, Rogers J, Bentley DR, Kwok PY, Mardis ER, Yeh RT, Schultz B, Cook L, Davenport R, Dante M, Fulton L, Hillier L, Waterston RH, McPherson JD, Gilman B, Schaffner S, Van Etten WJ, Reich D, Higgins J, Daly MJ, Blumenstiel B, Baldwin J, Stange-Thomann N, Zody MC, Linton L, Lander ES, Altshuler D (2001) A map of human genome sequence variation containing 1.42 million single nucleotide polymorphisms. Nature 409:928-933
Saito S, Iida A, Sekine A, Eguchi C, Miura Y, Nakamura Y (2001a) Seventy genetic variations in human microsomal and soluble epoxide hydrolase genes ( $E P H X 1$ and $E P H X 2)$ in the Japanese population. J Hum Genet 46:325-329

Saito S, Iida A, Sekine A, Miura Y, Sakamoto T, Ogawa C, Kawauchi S, Higuchi S, Nakamura Y (2001b) Identification of 197 genetic variations in six human methyltranferase genes in the Japanese population. J Hum Genet 46:529-537

Saito S, Iida A, Sekine A, Miura Y, Ogawa C, Kawauchi S, Higuchi S, Nakamura Y (2002a) Three hundred twenty-six genetic variations in genes encoding nine members of ATP-binding cassette, subfamily B (ABCB/MDR/TAP), in the Japanese population. J Hum Genet 47:38-50

Saito S, Iida A, Sekine A, Miura Y, Ogawa C, Kawauchi S, Higuchi S, Nakamura Y (2002b) Identification of 779 genetic variations in eight genes encoding members of the ATP-binding cassette, subfamily C (ABCC/MRP/CFTR). J Hum Genet 47:147-171

Sekine A, Saito S, Iida A, Mitsunobu Y, Higuchi S, Harigae S, Nakamura Y (2001) Identification of single-nucleotide polymorphisms (SNPs) of human N-acetyltransferase genes NAT1, NAT2, $A A N A T, A R D 1$ and $L 1 C A M$ in the Japanese population. J Hum Genet 46:314-319

Shani N, Jimenez-Sanchez G, Steel G, Dean M, Valle D (1997) Identification of a fourth half $\mathrm{ABC}$ transporter in the human peroxisomal membrane. Hum Mol Genet 6:1925-1931

Tyzack JK, Wang X, Belsham GJ, Proud CG (2000) ABC50 interacts with eukaryotic initiation factor 2 and associates with the ribosome in an ATP-dependent manner. J Biol Chem 275:34131-34139

Venkateswaran A, Repa JJ, Lobaccaro JM, Bronson A, Mangelsdorf DJ, Edwards PA (2000) Human white/murine ABC8 mRNA levels are highly induced in lipid-loaded macrophages. A transcriptional role for specific oxysterols. J Biol Chem 275:14700-14707

Williams BR (1991) Transcriptional regulation of interferonstimulated genes. Eur J Biochem 200:1-11

Zhou A, Hassel BA, Silverman RH (1993) Expression cloning of 2-5Adependent RNase: a uniquely regulated mediator of interferon action. Cell 72:753-765 